\title{
Feeding and reproduction by Calanus finmarchicus, and microzooplankton grazing during mesocosm blooms of diatoms and the coccolithophore Emiliania huxleyi
}

\author{
Jens C. Nejstgaard ${ }^{1, *}$, Ingrid Gismervik ${ }^{2}$, Paul T. Solberg ${ }^{1}$ \\ ${ }^{1}$ University of Bergen, Department of Fisheries and Marine Biology, Bergen High Technology Center, N-5020 Bergen, Norway \\ ${ }^{2}$ University of Oslo, Department of Biology, Section of Marine Chemistry and Marine Zoology, PO Box 1064 Blindern, \\ N-0316 Oslo, Norway
}

\begin{abstract}
The aim of this study was to quantify zooplankton feeding interactions and copepod reproduction during blooms of diatoms and flagellates (including Emiliania huxleyi) in fertilised mesocosms. A number of microzooplankton grazing (dilution series), copepod feeding (bottle incubation) and egg production experiments were performed during a 4 wk summer period. Microzooplankton (mainly ciliates) peaked during an initial bloom dominated by the diatom Skeletonema costatum and flagellates $\geq 10 \mu \mathrm{m}$, which apparently became grazer-controlled. Maximum grazing rates were 1.5 to $1.8 \mathrm{~d}^{-1}$ for diatoms, the calcifying haptophyte Emiliania huxleyi and flagellates 2 to $10 \mu \mathrm{m}$, and 65 to $80 \%$ of the average standing stock of these algae were removed daily. During a subsequent bloom of E. huxleyi the microzooplankton composition changed and its biomass decreased to $<25 \%$, and the daily turnover of diatoms and $E$. huxleyi fell to ca $50 \%$. In contrast to other algae, E. huxleyi specific growth was never surpassed by microzooplankton grazing. The copepod C. finmarchicus (CV and CVI females) preferred ciliates $\geq 30 \mu \mathrm{m}$, but ciliates $<30 \mu \mathrm{m}$, diatoms and rotifers were also occasionally preyed upon at high rates. E. huxleyi was barely ingested at low concentrations $\left(0.4\right.$ to $6 \times 10^{5}$ cells $\left.1^{-1}\right)$, but was cleared at $106 \mathrm{ml}$ ind.-1 $\mathrm{d}^{-1}$ at peak concentrations $\left(1.2 \times 10^{7}\right.$ cells $\left.\mathrm{l}^{-1}\right)$. It then made up $74 \%$ of total carbon ingestion. Although copepod ingestion rates were similar during blooms of diatoms and E. huxleyi, egg production rates were significantly higher during blooms of the latter, and mesozooplankton biomass increased 3 times more in mesocosms dominated by $E$. huxleyi compared to mesocosms with diatom blooms at similar algal biomass. Impact by copepods on the phytoplankton development was mainly induced indirectly by selective predation on the microzooplankton. A method to correct copepod feeding rate measurements for errors due to loss of microzooplankton grazing in the incubation bottles is presented.
\end{abstract}

KEY WORDS: Calanus - Microzooplankton - Emiliania Skeletonema - Grazing - Food selection Top-down $\cdot$ Reproduction - Mesocosm

\section{INTRODUCTION}

Zooplankton plays a pivotal role as a structuring force on the phytoplankton community in the sea (e.g. Riegman et al. 1993, Banse 1995, Verity \& Smetacek 1996). Traditionally mesozooplankton, such as copepods, has been identified as major grazers on the

\footnotetext{
•E-mail: jens.nejstgaard@ifm.uib.no
}

phytoplankton. However, it has become increasingly clear that microzooplankton plays a central role as grazers in marine planktonic food webs (e.g. Banse 1995, Waterhouse \& Welschmeyer 1995, and references therein). Microzooplankton is also an important component in the diet of copepods (e.g. Stoecker \& Capuzzo 1990, Kleppel 1993), and may support copepod egg production (Ohman \& Runge 1994). Due to the generally slower numerical response in mesozooplankton, compared to microzooplankton (Hansen 1992, 
Gismervik et al. in press), the major impact by copepods may be by selective predation on microzooplankton, rather than direct grazing on phytoplankton (Hansen et al. 1993, Kivi et al. 1993, 1996, Nielsen \& Kiorboe 1994).

Emiliania huxleyi is the dominant coccolithophorid in the world's oceans, and is a potentially important organism in global climate control (e.g. Westbroek et al. 1993, Heimdal et al. 1994, and references therein). However, its role in global circulation of climate gasses, such as $\mathrm{CO}_{2}$ and dimethylsulphide (DMS), is dependent on the interactions in the planktonic food web, as discussed in e.g. Harris (1994) and Levasseur et al. (1996). Literature on zooplankton grazing and reproduction during blooms of $E$. huxleyi is scarce, but studies in the laboratory and in the field have shown that this haptophyte may be significantly grazed by protozoa (Holligan et al. 1993, Wolfe et al. 1994), although when tested in polycultures, it was not a preferred food for heterotrophic dinoflagellates (Hansen et al. 1996). Laboratory studies have shown that $E$. huxleyi (when in bloom concentration) may support a comparatively high egg production in copepods such as Calanus spp. (Harris 1994, U Båmstedt, P. T. Solberg \& J. C. Nejstgaard unpubl.). However, Calanus spp. may have a lower retention efficiency for this alga than smaller copepods (Harris 1994), and E. huxleyi was not a preferred food type for Calanus finmarchicus during a previous mesocosm study (Nejstgaard et al. 1994).

Although it is well known that copepods may ingest diatoms at high rates (e.g. Frost 1972), and may produce a relative high number of eggs during diatomdominated blooms (e.g. Plourde \& Runge 1993, Kiørboe \& Nielsen 1994), recent findings question the role of diatoms as a key food and for reproductive success in copepods. Investigating several areas and copepod species, Kleppel et al. (1991) found no correlation between ambient diatom concentration and in situ egg production, whereas for dinoflagellates and microzooplankton there was a clear correlation. Series of laboratory and field studies report high mortality rates and abnormal development of eggs and nauplii when these species were fed common diatoms (Ianora et al. 1995, Poulet et al. 1995, Runge \& Starr 1996, Uye 1996, and references therein), while small haptophytes supported a high egg production and hatching success (Ianora et al. 1995; see also Støttrup \& Jensen 1990).

The present study investigates feeding by microzooplankton and Calanus finmarchicus during a diatom/ flagellate bloom and a monospecific bloom of Emiliania huxleyi. We address questions concerning selectivity of grazers, top-down control by microzooplankton and the copepod, and reproductive success of the copepod under different food regimes. We also discuss the succession of the phytoplankton bloom, and the success of the ubiquitous E. huxleyi. Finally, grazing rates based on cell numbers and chlorophyll a are evaluated, and we present a method to correct for errors in copepod feeding rate measurements due to loss of microzooplanktonic grazers in the copepod bottles during incubation.

\section{MATERIAL AND METHODS}

Mesocosms. The experiment was conducted during 4 wk in May-June 1994 at the marine biological field station of the University of Bergen, Norway. For a general description of the mesocosm design and location see Egge \& Heimdal (1994). On 13 May, 4 transparent polyethylene enclosures $\left(11 \mathrm{~m}^{3}, 2 \mathrm{~m}\right.$ diameter, open to the air) were attached to floating rings in the sea and filled with unfiltered nutrient depleted post-bloom water from $1 \mathrm{~m}$ depth. The entire water column in the mesocosms was kept homogenous by air lifts. On 14 May the mesocosms were fertilised to concentrations ố î $\mu$ moi $i^{-1}$ nitrate and $1 \mu m u i^{-1}$ pinuspilate. Tú two of them (NPS1 and 2) silicate was also added to obtain a concentration of $5 \mu \mathrm{mol} \mathrm{l}^{-1}$. Enclosures without silicate additions were termed NP1 and 2, respectively. From 16 May, $10 \%$ of the water was renewed daily with unfiltered water from $1 \mathrm{~m}$ depth, and nutrients were supplied every second day $20 \%$ of the initial nutrient additions, except on 20 May when $100 \%$ of the initial nutrient addition was supplemented to all mesocosms to allow further algae growth; cf. Egge \& Jacobsen (1997). Data on physics, nutrients and phytoplankton development in all 4 mesocosms is reported in Egge \& Jacobsen (1997), and may be summarized as follows: The irradiance was stable and averaged $38.3 \mathrm{~mol} \mathrm{~m}^{-2} \mathrm{~d}^{-1}$ during the first half of the experiment. but decreased to an average of $16.2 \mathrm{~mol} \mathrm{~m}^{-2} \mathrm{~d}^{-1}$ from 30 May through 9 June. The water temperature fluctuated between 8.0 and $11.5^{\circ} \mathrm{C}$, and salinity increased from 28.5 to $30.0 \mathrm{PSU}$, during the experimental period. Blooms of diatoms, such as Skeletonema costatum, dominated the phytoplankton in both NPS mesocosms, while both NP mesocosms showed a smaller initial bloom of diatoms (mainly $S$. costatum), but became completely dominated by Emiliania huxleyi during the second half of the experiment. Integrated for the whole period, phytoplankton carbon production in the NPS mesocosms was twice the carbon production in the NP mesocosms, allthough equal amounts of nitrate and phosphate, respectively, was consumed in all 4 mesocosms.

Mesozooplankton were sampled in all mesocosms on 15 May with a $20 \mathrm{~cm}$ diameter, $30 \mu \mathrm{m}$ mesh net hauled vertically from the bottom of the mesocosms, and on 
20 June, by pumping the entire volume of each mesocosm through a $200 \mu m$ net. In NP1 an additional sample was taken with the $30 \mu \mathrm{m}$ mesh net on $13 \mathrm{June}$. Water for analysis of chlorophyll (chl) a, nutrients and protist abundance in NP1 were sampled on 6 occasions between 15 May and 13 June.

Experiments. The laborious processing of the samples (see below) severely limits the maximal number of manageable experiments. Thus the bulk of experimental work was conducted with water from only one mesocosm, NP1, as the NP mesocosms were expected to show phytoplankton successions including both diatoms and flagellates (compare e.g. Egge \& Heimdal 1994). In the egg production experiments, water from NPS1 was used in addition to that from NP1 for comparison purposes. We conducted 5 dilution experiments (Landry \& Hassett 1982) to estimate phytoplankton growth and microzooplankton grazing (D1 to D5), 4 overnight incubations to quantify grazing by Calanus finmarchicus (C1 to C4), 2 four-day incubations to determine direct feeding effects of $C$. finmarchicus on the plankton development (L1 and L2), and 2 series of egg and faecal pellet production experiments with $C$. finmarchicus ( $\mathrm{E} 1$ and $\mathrm{E} 2$ ); see Table 1 for the experimental and sampling design, and Fig. 1 for the timing of the experiments. To avoid unnecessary changes in the experimental nutrient conditions (e.g. Landry 1993), no nutrients were added to the bottles in Expts D1 to D4. However, at the time of D4 the concentration of nitrate reached the detection level and D5 was conducted as 2 parallel series; one without addition of nutrients (D5) and one with added nitrate and phosphate equivalent to 16 and $1 \mu \mathrm{mol} \mathrm{l}^{-1}$, respectively (D5+NP). Copepods for the experiments were collected from the surface water $(\leq 20 \mathrm{~m}$ ) of the nearby Raunefjorden, using a $1 \mathrm{~m}$ diameter $200 \mu \mathrm{m}$ mesh net, with a 141 non-filtering codend. Actively swimming undamaged copepods were sorted out using widemouth pipettes within $1 \mathrm{~h}$ after collection. All bottles were incubated in situ outside the mesocosms hanging on strings from a floating ring at $2 \mathrm{~m}$ depth. Egg production experiments were conducted in a cold room at in situ temperature $\left(10^{\circ} \mathrm{C}\right)$, with reference series of females fed surplus concentrations (ca $900 \mu \mathrm{g}$ carbon $1^{-1}$; cf. Nejstgaard et al. 1995) of the phytoflagellate Rhodomonas baltica (ca $8 \mu \mathrm{m}$ cell diameter), which is a well-studied food for cultures of copepods (cf. Støttrup \& Jensen 1990).

Care was taken to handle the microzooplankton as gently as possible. In L1, 1 l per bottle was subsampled at the start and after 1,2 and 4 d of the incubation by gentle siphoning, using a hose fitted with a $200 \mu \mathrm{m}$ mesh on a funnel to exclude copepods. Sampled volume was not replaced. In all other experiments bottles were terminated when sampled. A large volume syringe fitted with a silicone hose was used to sample microzooplankton and algae directly in the bottles. Thereafter copepods were screened on $200 \mu \mathrm{m}$ submerged net and were immediately counted and examined for stage and viability under a dissecting microscope before being fixed in $4 \%$ hexamine buffered formaldehyde. Samples for chl a were taken, and the remaining water was screened for particles $>40 \mu \mathrm{m}$, fixed in formaldehyde, and later enumerated for less abundant, larger sized plankton such as Ceratium spp., rotifers and nauplii.

Analysis of the samples. Duplicate chl a samples were filtered onto $47 \mathrm{~mm} 0.45 \mu \mathrm{m}$ pore size nitrocellulose filters (differential pressure $<6 \mathrm{~mm} \mathrm{Hg}$ ), and in some cases also onto duplicate $47 \mathrm{~mm} 10 \mu \mathrm{m}$ pore size (cf. Table 1) and $5 \mu \mathrm{m}$ pore size (samples from NP1mesocosm) polycarbonate filters (using gravity by sample only). Samples were frozen $\left(-22^{\circ} \mathrm{C}\right)$ for no more than $3 \mathrm{~d}$, then extracted in $90 \%$ acetone and measured on a Turner Designs Model 10-AU fluorometer according to the new method without acidification (Welschmeyer 1994). Nutrients were analysed on a Skalar autoanalyser, using freshly collected samples, or samples preserved with chloroform and stored overnight at $4^{\circ} \mathrm{C}$ before analysis (15, 27 May and 13 June).

Phytoplankton samples were fixed in both acid and neutral $1 \%$ (vol/vol) Lugol's solution. The acid Lugol yielded overall slightly higher cell numbers compared to the neutral Lugol, and there were no consistent difference in cell numbers of Emiliania huxleyi between these fixatives, or when compared to samples fixed in neutral formaldehyde and counted by Egge \& Jacobsen (1997). Therefore only samples fixed in acid Lugol's solution were used for further analysis. Due to limited means for sample processing, phytoplankton samples from dilution bottles in Expt D5 and from the termination of L2 were not analysed.

Algae and ciliate samples were settled in $50 \mathrm{ml}$ sediment chambers (Hasle 1969). Ciliates were counted in the whole chamber at $250 \times$ magnification, and sized at $400 \times$ magnification. Cell volume was calculated using simple geometrical formulas (Ohman \& Snyder 1991) and carbon and nitrogen were calculated by conver-

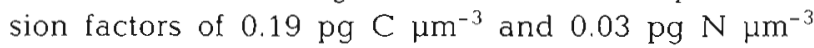
respectively (Putt \& Stoecker 1989). Dinoflagellates were counted and sized in half the chamber at $300 \times$, and other algae were counted and sized at $600 \times$ in 2 diagonals equivalent to $652 \mu \mathrm{l}$ of the sample. Dominating ciliate species were determined to species by the QPS (quantitative protargol stain) method (Montagnes \& Lynn 1993). Phytoplankton carbon and nitrogen was calculated by multiplying cell numbers by specific conversion factors from the literature (Edler 1977, Moal et al. 1987, Verity et al. 1992, Montagnes et al. 1994). Edler (1977) was used for diatom carbon only. Values 
literature (Båmstedt 1986، Båmstedt et al. 1990, Blom et al. 1991, Widdows 1991, Karlson \& Båmstedt 1994). Nauplii and rotifers were converted into nitrogen by a factor of $0.078 \mathrm{~N}$ :DW adapted from Bamstedt (1986). Copepod faecal pellets collected from the $40 \mu \mathrm{m}$ net samples (C2 and C4) and $200 \mu \mathrm{m}$ copepod samples (C3) were analysed for coccolith content using SEM. Faecal pellets from $\mathrm{C} 2$ and $\mathrm{C} 4$ were sized under a light microscope at $400 \times$ for determination of average pellet volume ( $\mathrm{n}=16$ per sample, assuming cylinder-shape with spherical ends). Pellet breakage was taken into account by combining adjacent obviously broken parts into single pellets, both when counting daily samples from the production flasks and during the subsequent sizing of pellets. Thus, errors in counting and sizing of the pellets should counteract one another so as to minimise the total error in faecal pellet volume determinations. Biomass of Calanus finmarchicus was calculated from the specific dry weights of copepadid stage V (CV) $(185 \mu \mathrm{g})$ and CIV $(97.5 \mu \mathrm{g})$ collected in the same fjord and season a previous year (Karlson \& Båmstedt 1994). Dry weight was converted into carbon by a factor of $0.547 \mathrm{C}: \mathrm{DW}$ (Båmstedt 1986) for copepods from high latitudes. Numbers of egg produced were recalculated into carbon and nitrogen by the conversion factors $0.23 \mu \mathrm{g}$ carbon $\mathrm{egg}^{-1}$ and $0.0435 \mu \mathrm{g}$ nitrogen egg ${ }^{-1}$ (Hirche 1990, Ohman \& Runge 1994).

Calculations. Growth and grazing: Algal growth rates, microzooplankton grazing coefficients and daily grazing impact were calculated according to the original method by Landry \& Hassett (1982). To account for possible saturation of the microzooplankton feeding (cf. Gallegos 1989), the data were also tested for nonlinearity by polynomial regression analysis of apparent growth rate versus fraction of undiluted water $(x)$ (cf. Andersen et al. 1991). For data sets where significant nonlinearity $(p<0.05$, for quadratic or higher terms in $x$ ) was found, we used a modified version of Gallegos' (1989) 3-point method, including not only the lowest 2 fractions, but all fractions $\leq 0.5 x$. The microzooplankton biomass changed little during the incubations (growth rate, $\mu$, in undiluted bottles $\mathrm{ca} \pm 0$ to $0.2 \mathrm{~d}^{-1}$ ). Thus we assumed no microzooplankton net growth during the incubations, although the composition of the microzooplankton changed somewhat.

Copepod clearance and ingestion rates were calculated according to Frost (1972). Negative clearance rates were interpreted as zero ingestion. However, high predation rates by the copepods on microzooplankton have probably led to an underestimation of the copepod grazing rates on prey also grazed by microzooplankton. Thus we made a simple and conservative correction for loss by microzooplankton grazing in the copepod bottles, assuming that: (1) each microzooplankter ingested prey from within a defined spectrum of prey only (i.e. feeding guild, defined in Table 2), (2) the microzooplankton ingested all prey types within their feeding guild in direct proportions to the prey concentration, and (3) microzooplankton grazing rates were uniformly proportional to body carbon for all microzooplankton species, for each prey type in each experiment. The copepod grazing rates were corrected for each prey type $(p)$ and copepod incubation bottle, according to:

$$
g_{\text {corr }, p}=g_{\text {cop }, p}+k_{p}
$$

where $g_{c o r r, p}$ is the corrected copepod grazing coefficient for prey type $p\left(\mathrm{~d}^{-1}\right), g_{c o p}, \mathrm{p}$ is the uncorrected

Table 2. Main feeding guilds defined for the different taxonomic groups of microzooplankton (Predator species)

\begin{tabular}{|c|c|c|c|c|c|c|c|c|c|}
\hline \multirow{2}{*}{ Predator species } & \multirow[b]{2}{*}{$\begin{array}{l}\text { Ciliates } \\
\geq 35 \mu \mathrm{m}\end{array}$} & \multirow[b]{2}{*}{$\begin{array}{l}\text { Ciliates } \\
<35 \mu \mathrm{m}\end{array}$} & \multirow[b]{2}{*}{$\begin{array}{l}\text { Dino- } \\
\text { flagellates }\end{array}$} & \multirow{2}{*}{ Diatoms } & \multirow{2}{*}{$\begin{array}{l}\text { species } \\
\text { Flagellates } \\
\geq 10 \mu \mathrm{m}\end{array}$} & \multirow[b]{2}{*}{$\begin{array}{l}\text { Emiliania } \\
\text { huxleyi }\end{array}$} & \multirow[b]{2}{*}{$\begin{array}{l}\text { Flagellates } \\
2-10 \mu \mathrm{m}\end{array}$} & \multirow{2}{*}{$\begin{array}{l}\text { Plankton } \\
<2 \mu \mathrm{m}\end{array}$} & \multirow{2}{*}{$\begin{array}{l}\text { Refer- } \\
\text { ences }\end{array}$} \\
\hline & & & & & & & & & \\
\hline Predatory ciliates $\geq 35 \mu \mathrm{m}$ & $x$ & $x$ & $x$ & & & & & & $1,3,4$ \\
\hline Copepodids $^{a}$ & $x$ & $x$ & $x$ & $x$ & $x$ & & & & $5,6,7$ \\
\hline Heterotrophic dinoflagellates & $x$ & $x$ & $x$ & $x$ & $x$ & $x$ & $x$ & & $8,9,10$ \\
\hline Nauplii & & $x^{b}$ & $x^{b}$ & $x$ & $x$ & $x$ & $x$ & & 8 \\
\hline Rotifers & & & & $\times$ & $x$ & $x$ & $x$ & & 8 \\
\hline Non-predatory ciliates $\geq 35 \mu \mathrm{m}$ & & & & $x$ & $x$ & $x$ & $x$ & & $1,2,3$ \\
\hline Ciliates $<35 \mu \mathrm{m}$ & & & & & & $x$ & $x$ & $x$ & $1,2,3$ \\
\hline Choanoflagellates & & & & & & & & $x$ & 8,11 \\
\hline \multicolumn{10}{|c|}{$\begin{array}{l}\text { a Copepodids in the } 200 \mu \mathrm{m} \text { screened incubation water was completely dominated by Oithona spp. } \\
\text { b Some of these prey items may be too large for the nauplii (mainly calanoid). However, these are included to give a conserv- } \\
\text { ative estimate of corrected copepod predation in Table } 4 \text {, as the biomass of nauplii was not affected by copepod predation } \\
\text { (cf. Table } 6 \text { ) }\end{array}$} \\
\hline \multicolumn{10}{|c|}{$\begin{array}{l}\text { References: 'Jonsson (1986, and pers. comm.), }{ }^{2} \text { Kivi \& Setälä (1995), }{ }^{3} \text { Dolan }(1991),{ }^{4} \text { Hansen }(1991),{ }^{5} \text { Tsuda \& Nemoto }(1988), \\
{ }^{6} \text { Turner (1994, and references therein), }{ }^{7} \text { Nielsen \& Sabatini (1996, and references therein), }{ }^{8} \text { Hansen et al. (1994 and refer- } \\
\text { ences therein), }{ }^{9} \text { Lessard (1991), }{ }^{10} \text { Schnepf \& Elbrächter (1992), }{ }^{11} \text { Eccleston-Parry \& Leadbeater (1994) }\end{array}$} \\
\hline
\end{tabular}


copepod grazing coefficient for prey type $p$ according to Frost (1972), and $k_{p}$ is the correction for loss of microzooplankton grazing on prey type $p$ in the copepod bottle. $k_{p}$ was calculated according to:

$$
k_{p}=g_{\text {mic }, p}\left(\frac{\sum_{s=1}^{n}\left(\bar{c}_{s}-\bar{c}_{s}{ }^{*}\right)}{\sum_{s=1}^{n} \bar{c}_{s}}\right)
$$

where $g_{\text {muc, } p}$ is the microzooplankton grazing coefficient for prey type $p\left(\mathrm{~d}^{-1}\right.$, obtained from simultaneously performed dilution experiments), $\bar{C}_{s}$ and $\bar{c}_{s}{ }^{*}$ are the average concentrations of microzooplankton species $s$ ( $\mu \mathrm{g} \mathrm{C} \mathrm{l}^{-1}$ ) in the blank and copepod bottles respectively, and $n$ is the number of the microzooplankton species defined as predators on prey type $p$. Average microzoopiankton concentrations were caiculated according to the following equations, adapted from Frost (1972):

$$
\begin{aligned}
& \bar{C}_{s}=\left(C_{S} t-C_{s} 0\right) / \ln \left(C_{S} t / C_{S} 0\right) \\
& \bar{C}_{s}^{*}=\left(C_{S} t^{*}-C_{S} 0\right) / \ln \left(C_{S} t^{*} / C_{S} 0\right)
\end{aligned}
$$

where $c_{s} 0$ is the concentration of species $s$ at the start of the incubation, while $c_{S}$ and $c_{S} t^{*}$ are the concentrations of species $s$ at the end of the incubation in the blank (average for all blanks) and copepod bottles, respectively.

Copepod prey preference index: Copepod prey preference was calculated as Manly's (1974) index for variable prey populations, which is recommended when the predator consumes a substantial fraction of the prey during the experiment (Chesson 1983):

$$
\hat{\alpha}_{i}=\frac{\ln \left[\left(n_{i} 0-r_{i}\right) / n_{i} 0\right]}{\sum_{j=1}^{m} \ln \left[\left(n_{j} 0-r_{j}\right) / n_{j} 0\right]}, \quad i=1, \ldots, m
$$

where $\hat{\alpha}_{1}$ is the preference for prey type $i_{1} r_{i}$ is the amount of prey type $i$ consumed by the predator ( $\mu \mathrm{g} C$ ind ${ }^{-1} \mathrm{~d}^{-1}$ ), here normalised for copepod concentration, assuming that all copepods have identical feeding behaviour (cf. Chesson 1983), and $m$ is the number of prey types in the environment. In the original equation, $n_{1} 0$ is the concentration of prey type $i$ at the start of the experiment, i.e. the prey available in an environment unaffected by the predator. However, to account for growth or mortality of the prey not due to copepod predation during the incubation, we replaced $n_{i} 0$ with the average concentration of prey type $i$ present in the blank during the experiment $\left(\bar{n}_{1}^{\prime}\right)$, calculated similar to $\bar{c}_{s}$ in Eq. 3 .

\section{RESULTS}

\section{Succession of nutrients and phytoplankton in the NP1 mesocosm}

The nitrate concentration decreased during the first $5 \mathrm{~d}$, but reached a new maximum after the re-supply on 20 May (Fig. 1A). However, it fell rapidly thereafter

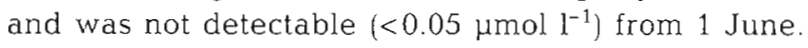
Phosphate and silicate concentrations decreased at lower rates and never fell below 0.19 and $0.38 \mu \mathrm{mol} \mathrm{l}^{-1}$, respectively.

The development of chl $a$ in mesocosm NP1 indicated 2 phytoplankton maxima (Fig. 1B). The first bloom was dominated by diatoms and flagellates (Fig. 1C, D). The relatively small Skeletonema costatum (ca $5 \mu \mathrm{m}$ cell diameter $\times 14 \mu \mathrm{m}$ length) made up 68 to $88 \%$ of the diatom carbon between 15 and 24 May, followed by dominance of Pseudonitzschia sp. (ca $4 \times$ $50 \mu \mathrm{m}$ ) (50 to $76 \%$ between 27 May and 1 June). Diatoms made up $<1 \%$ of the phytoplankton carbon after 3 June (Fig. 1D). The biomass of flagellates $\geq 10$ jinn consisted of $>90 \%$ of 12 to 15 jiñ cryptóphyceans during the first bloom. Flagellates 2 to $10 \mu \mathrm{m}$, plastidic dinoflagellates, and the obligate autotrophic ciliate Myrionecta rubra (formerly Mesodinium rubrum) never contributed much to the phytoplankton biomass (Fig. 1D). The second bloom was completely dominated by Emiliania huxleyi. Its abundance was low at the beginning of the mesocosm experiment $(3.8 \times$ $10^{4}$ cells $\mathrm{l}^{-1}$ ), but increased rapidly during the decline of the first bloom, and reached a maximum of $2.5 \times$ $10^{7}$ cells $l^{-1}$ on 3 July. E. huxleyi then made up $88 \%$ of the total plankton organic carbon, increasing to $95 \%$ by the end of the investigated period.

Fig. 1 Development in mesocosm NP1 between $15 \mathrm{May}$ and 13 June 1994, and starting time for the microzooplankton dilution experiments (D1 to D4), overnight copepod incubations (C1 to C4), $4 \mathrm{~d}$ copepod incubations ( $\mathrm{L} 1$ and L2), and egg production experiments (E1, E2a and E2b). (A) Inorganic nutrient concentrations (note that phosphate and silicate are multiplied by 10 for convenience). (B) Chlorophyll a particulate fractions. (C) Autotrophic protist abundance in cell numbers; flag. = flagellates (only species containing chloroplasts); $M y r i-$ onecta $=M$. rubra (autotrophic ciliate $<30 \mu \mathrm{m})_{i}$ Emiliania $=E$. huxleyi. Note that data from 3 June are only presented for $E$. huxleyi and diatoms (from neutral formaldehyde sample, Egge \& Jacobsen 1997), other data are interpolated. (D) As (C), but in terms of carbon. (E) As (C), and (F) as (D), but heterotrophic species only; aplastidic dinoflagellates (het.), Choanoflagellates are $<10 \mu \mathrm{m}$. (G) Metazoan cell numbers and $(\mathrm{H})$ Metazoan carbon concentration; copepodids of Calanus finmarchicus ( $C$. fin . cop.), other calanoid copepodids (Other cal. cop.), cyclopoid copepodids (Cyclo, cop.), and other metazoans (Other) are interpolated between 15 May and 13 June 

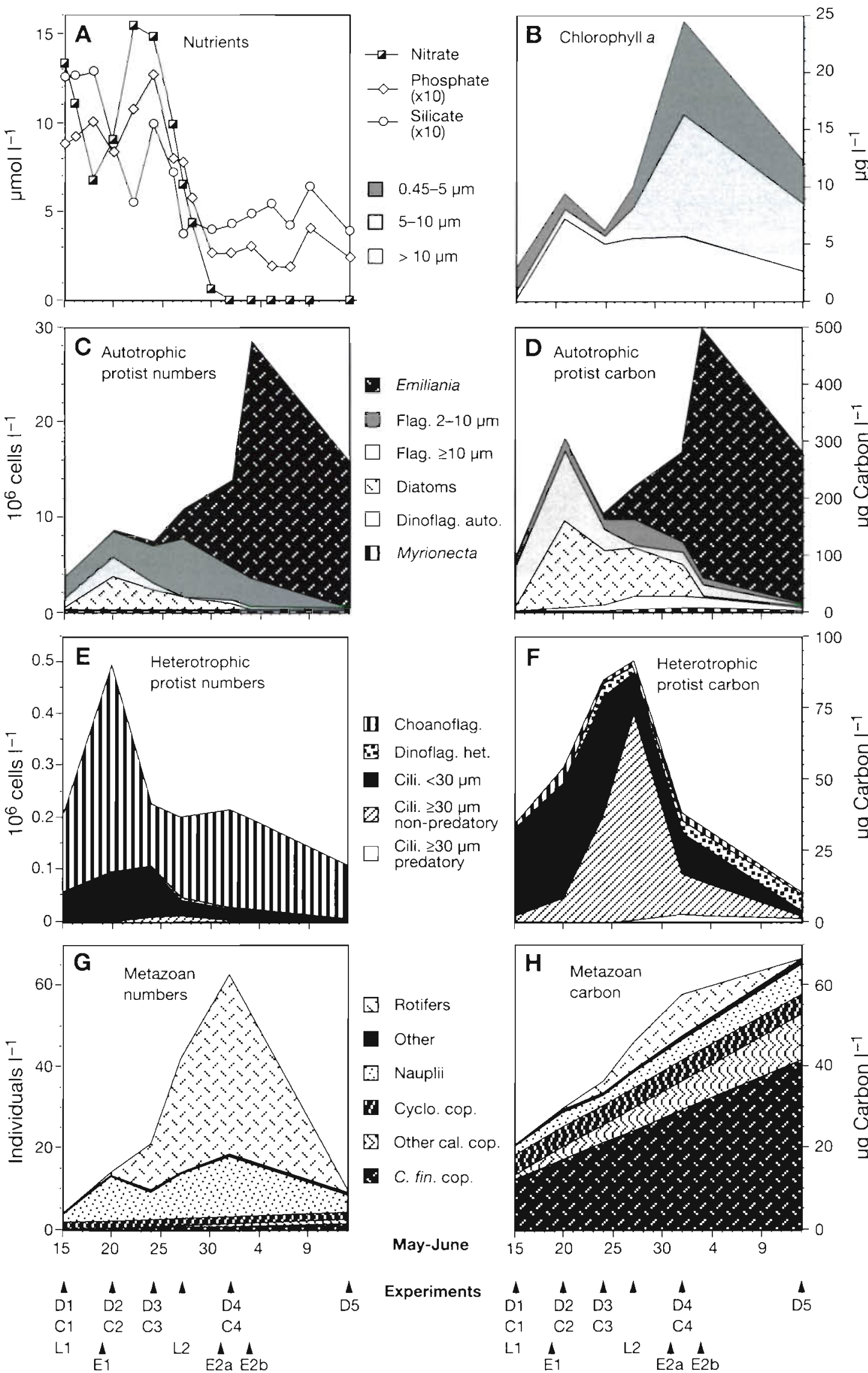

May-June

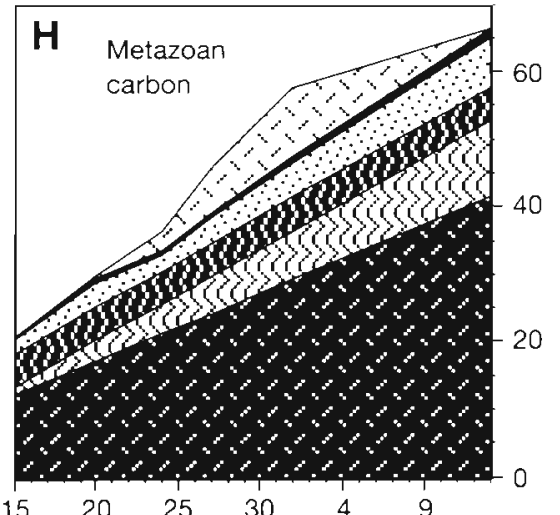

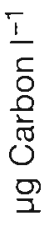

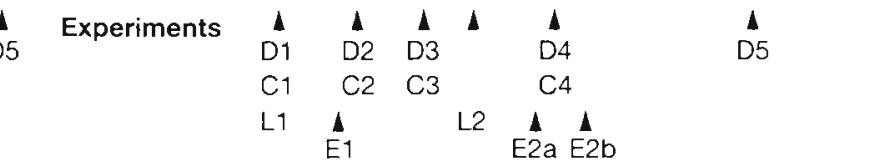




\section{Heterotrophic plankton in the NP1 mesocosm}

The development of obligate heterotrophic (aplastidic) protists and metazoans in the mesocosm is shown in Fig. 1E-H. Subsequent to the diatom/flagellate bloom the heterotrophic biomass peaked due to a rapid increase in ciliates. In contrast, during the bloom of Emiliania huxleyi all ciliates except predatory species declined rapidly, resulting in a decrease in total heterotrophic biomass and an increase in the relative importance of rotifers, heterotrophic dinoflagellates, nauplii and copepodids. There was a shift in ciliate species composition during the investigated period. Ciliates $<30 \mu \mathrm{m}$ dominated the ciliate carbon the first week, while larger species were important by the end of May, and finally a significant increase in predatory species occurred in mid-June (Fig. 1E, F). Nevertheless, small ciliates were most abundant on all occasions except 27 May. Both size groups consisted mainly of oligotrich species like Strombidium spp. and Strobilidium spp., which dominated the ìrger ciliates, and Lohmaniella oviformis, which made up between 48 and $95 \%$ of the carbon in the smallest size group. However, a scuticociliate made up ca $30 \%$ of the carbon in the smallest size group in Expt C2. Predatory species were comprised of a suctorian, cf. Acineta sp. and 2 haptorids cf. Monodinium sp. and $\mathrm{cf}$. Cyclotrichium sp. Tintinnids were not important (always $<3 \%$ of the total ciliate carbon). Heterotrophic dinoflagellates were only important in the last dilution experiment (D5, Fig. 1F), when they made up $25 \%$ of the heterotrophic carbon in the $200 \mathrm{~m}$ pre-screened incubation water (not shown). Their biomass was mainly due to Protoperidinium bipes ( 0 to $28 \%$ ) and an undetermined species of 20 to $30 \mu \mathrm{m}$ length 10 to $35 \%$ ). Small (5 to $10 \mu \mathrm{m}$ ) choanoflagellates were abundant, but contributed little to the biomass (Fig. 1E, F).

Calanus finmarchicus dominated the metazoan biomass (Fig. $1 \mathrm{G}, \mathrm{H}$; note however that we only sampled larger zooplankton in NP1 on 15 May, 13 and 20 June). Other calanoid copepods were Temora longicornis, Pseudocalanus elongatus and Paracalanus sp., while cyclopoids were Oithona spp. Rotifers and nauplii occurred in high numbers, but always represented $<18$ and $<12 \%$ of the metazoan carbon, respectively (Fig. 1G, H).

\section{Microzooplankton grazing and algal growth}

The microzooplankton grazed the phytoplankton at high rates, and ingested between 20 and $87 \%$ of the average standing stock daily, depending on taxa (Table 3). High grazing coefficients were found for flagellates 2 to $10 \mu \mathrm{m}$ in all experiments 1.06 to $\left.2.06 \mathrm{~d}^{-1}\right)$, and for diatoms $\left(1.13\right.$ to $\left.1.76 \mathrm{~d}^{-1}\right)$ and Emiliania huxleyi (1.01 to $1.48 \mathrm{~d}^{-1}$ ) in Expt D1 to D3. Polynomial regression revealed significant non-linearities $(\mathrm{p}<0.05)$ for diatoms and dinoflagellates in D1, and diatoms, E. huxleyi and flagellates 2 to $10 \mu \mathrm{m}$ in D4 (Fig. 2).

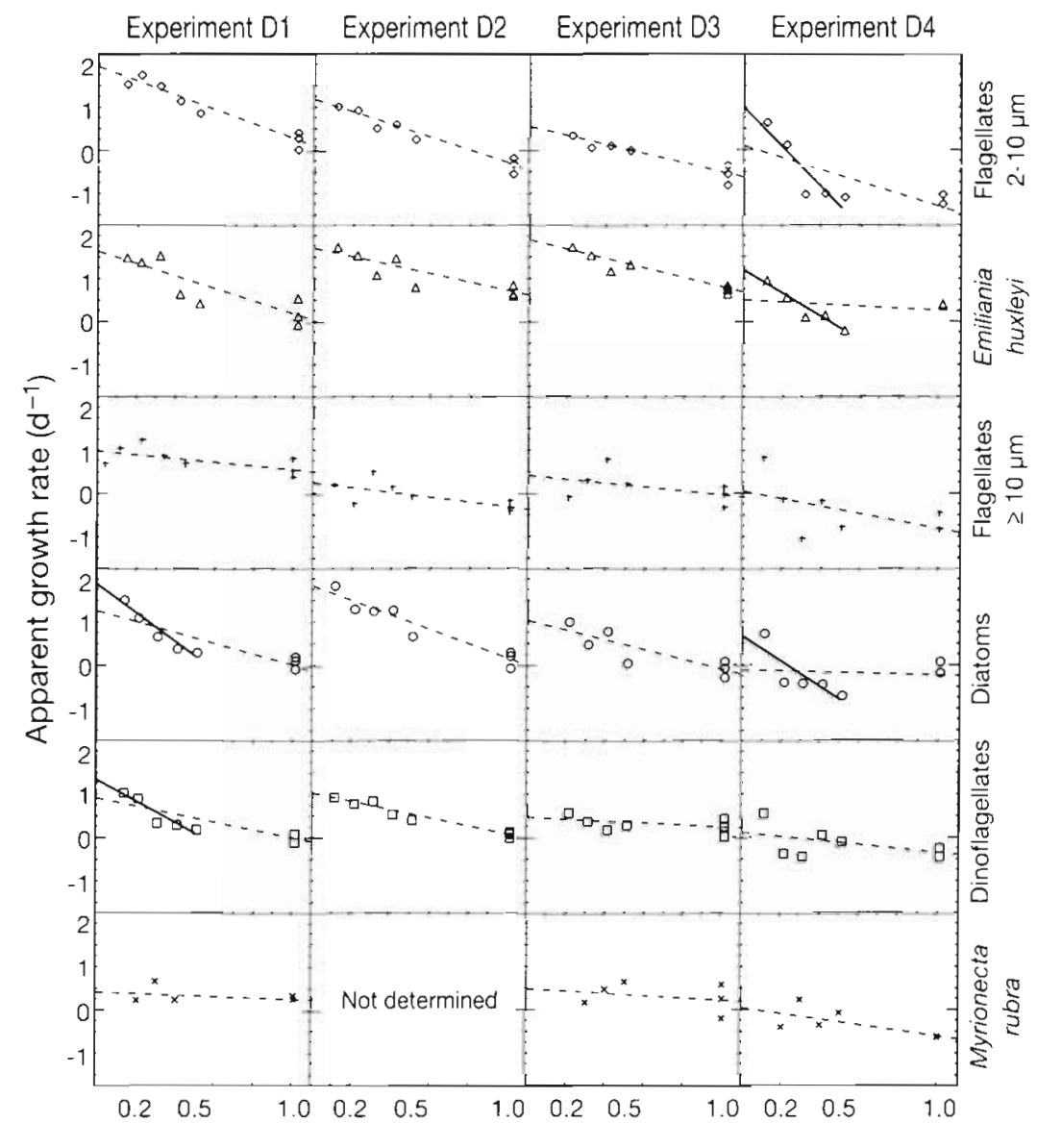

Fraction unfiltered mesocosm water

Fig. 2. Microzooplankton grazing experiments D1 to D4. Apparent daily growth rates as a function of fraction unfiltered water from the mesocosm, based on microscopic cell counts. Aplastidic flagellates and dinoflagellates and all Ceratium species are excluded. Myrionecta rubra data not analysed for the lowest fractions due to low counts. Dashed lines indicate linear regressions fitted to all data points. Solid lines indicate linear regressions fitted to data points for diluted samples only according to the modified 3-point method (see text) 
Table 3. Dilution experiments D1 to D5. Specific algal growth rate $\left(\mu ; \mathrm{d}^{-1}\right)$, microzooplankton grazing coefficient ( $g$; $\left.\mathrm{d}^{-1}\right)$, net algal growth rates in undiluted bottles $\left(k_{i} \mathrm{~d}^{-1}\right)$, and grazing impact as percentage of average standing stock removed $\mathrm{d}^{-1} \mu$ and $g$ are based on linear regression fitted to all data points by the least square method (regression), and in cases of significant nonlinearity (cf. Fig. 2) rates are also calculated according to the modified 3-point method (3-point) (see text). \pm SE for the mean. " $p<0.05$, $\cdots p<0.01, \cdots p<0.001$ for $\mu$ or $g=0$ (regression), and $k=0$ (2-tailed $t$-test), respectively. Bottles in D5+NP are added surplus amounts of nitrate and phosphate

\begin{tabular}{|c|c|c|c|c|c|c|c|c|c|c|}
\hline \multirow[t]{2}{*}{ Prey type } & \multirow{2}{*}{$\begin{array}{c}\text { Expt } \\
\text { no. }\end{array}$} & \multicolumn{2}{|c|}{ Regression } & \multirow[t]{2}{*}{$n$} & \multirow[t]{2}{*}{$r^{2}$} & \multicolumn{2}{|c|}{ 3-point } & \multirow{2}{*}{$\underset{k}{\text { Net growth }}$} & \multirow[t]{2}{*}{$\mathrm{n}$} & \multirow{2}{*}{$\begin{array}{l}\text { Grazing } \\
\text { impact }\end{array}$} \\
\hline & & $\mu$ & $g$ & & & $\mu$ & $g$ & & & \\
\hline Chl $a>0.45 \mu \mathrm{m}$ & $\begin{array}{c}1 \\
2 \\
3 \\
4 \\
5 \\
5+\mathrm{NP}\end{array}$ & $\begin{array}{c}0.85 \pm 0.09 \cdots \\
1.22 \pm 0.04 \cdots \\
0.59 \pm 0.10^{\cdots} \cdots \\
0.12 \pm 0.03 * \\
-0.12 \pm 0.05 \\
-0.17 \pm 0.03 \cdots\end{array}$ & $\begin{array}{l}0.37 \pm 0.14^{\circ} \\
0.57 \pm 0.05^{\cdots} \cdots \\
0.45 \pm 0.14^{\circ} \\
0.18 \pm 0.06^{\circ} \\
0.23 \pm 0.09 \\
0.05 \pm 0.05\end{array}$ & $\begin{array}{l}8 \\
8 \\
7 \\
7 \\
6 \\
6\end{array}$ & $\begin{array}{l}0.54 \\
0.95 \\
0.68 \\
0.67 \\
0.61 \\
0.15\end{array}$ & & & $\begin{array}{l}0.50 \pm 0.11 \\
0.67 \pm 0.02 \cdots \\
0.14 \pm 0.11 \\
-0.04 \pm 0.02 \\
-0.31 \\
-0.22\end{array}$ & $\begin{array}{l}3 \\
3 \\
3 \\
2 \\
1 \\
1\end{array}$ & $\begin{array}{r}31 \\
43 \\
36 \\
16 \\
21 \\
4\end{array}$ \\
\hline Flagellates $2-10 \mu \mathrm{m}^{\mathrm{a}}$ & $\begin{array}{l}1 \\
2 \\
3 \\
4\end{array}$ & $\begin{array}{l}1.97 \pm 0.12 \cdots \\
1.20 \pm 0.10 \cdots \\
0.56 \pm 0.13 \cdots \\
0.12 \pm 0.39\end{array}$ & $\begin{array}{l}1.69 \pm 0.18 \cdots \\
1.49 \pm 0.15 \cdots \\
1.06 \pm 0.18 \cdots \\
1.41 \pm 0.65\end{array}$ & $\begin{array}{l}8 \\
8 \\
7 \\
7\end{array}$ & $\begin{array}{l}0.93 \\
0.94 \\
0.87 \\
0.49\end{array}$ & 0.99 & 2.06 & $\begin{array}{r}0.30 \pm 0.12 \\
-0.27 \pm 0.11 \\
-0.50 \pm 0.13 \\
-1.07 \pm 0.11\end{array}$ & $\begin{array}{l}3 \\
3 \\
3 \\
2\end{array}$ & $\begin{array}{l}81 \\
77 \\
65 \\
87^{d}\end{array}$ \\
\hline Emiliania huxleyi & $\begin{array}{c}1 \\
2 \\
3 \\
4 \\
5 \\
5+\mathrm{NP}\end{array}$ & $\begin{array}{l}1.67 \pm 0.23 \cdots \\
1.73 \pm 0.15 \cdots \\
1.91 \pm 0.11 \cdots \\
0.53 \pm 0.26 \\
\text { Not determined } \\
\text { Not determined }\end{array}$ & $\begin{array}{l}1.48 \pm 0.34 \cdots \\
1.01 \pm 0.23 \cdots \\
1.11 \pm 0.15 \cdots \\
0.25 \pm 0.43\end{array}$ & $\begin{array}{l}8 \\
8 \\
7 \\
7\end{array}$ & $\begin{array}{l}0.76 \\
0.76 \\
0.91 \\
0.06\end{array}$ & 1.20 & 0.74 & $\begin{array}{l}0.27 \pm 0.18 \\
0.77 \pm 0.07 \cdots \\
0.82 \pm 0.06 \cdots \\
0.46 \pm 0.01^{\circ} \\
-0.62 \\
-0.20\end{array}$ & $\begin{array}{l}3 \\
3 \\
3 \\
2 \\
1 \\
1\end{array}$ & $\begin{array}{l}77 \\
63 \\
67 \\
52^{c}\end{array}$ \\
\hline Flagellates $\geq 10 \mu \mathrm{m}$ & $\begin{array}{l}1 \\
2 \\
3 \\
4\end{array}$ & $\begin{array}{l}1.05 \pm 0.15 \cdots \\
0.27 \pm 0.16 \\
0.43 \pm 0.28 \\
0.07 \pm 0.40\end{array}$ & $\begin{array}{l}0.48 \pm 0.23 \\
0.56 \pm 0.24 \\
0.45 \pm 0.39 \\
0.88 \pm 0.66\end{array}$ & $\begin{array}{l}8 \\
8 \\
7 \\
7\end{array}$ & $\begin{array}{l}0.42 \\
0.47 \\
0.21 \\
0.26\end{array}$ & & & $\begin{aligned} 0.57 & \pm 0.13 \\
-0.31 & \pm 0.07 \\
-0.06 & \pm 0.14 \\
-0.64 & \pm 0.18\end{aligned}$ & $\begin{array}{l}3 \\
3 \\
3 \\
2\end{array}$ & $\begin{array}{l}38 \\
43 \\
36 \\
59\end{array}$ \\
\hline Diatoms & $\begin{array}{l}1 \\
2 \\
3 \\
4\end{array}$ & $\begin{aligned} 1.29 & \pm 0.20 \cdots \\
1.86 & \pm 0.14 \cdots \\
1.04 & \pm 0.22 \cdots \\
-0.09 & \pm 0.35\end{aligned}$ & $\begin{array}{l}1.27 \pm 0.30^{\circ} \\
1.69 \pm 0.21^{\cdots} \\
1.13 \pm 0.30^{\circ} \\
0.12 \pm 0.58\end{array}$ & $\begin{array}{l}8 \\
8 \\
7 \\
7\end{array}$ & $\begin{array}{l}0.75 \\
0.92 \\
0.74 \\
0.01\end{array}$ & 1.87 & $\begin{array}{l}1.76 \\
0.69\end{array}$ & $\begin{array}{r}0.11 \pm 0.08 \\
0.20 \pm 0.12 \\
-0.05 \pm 0.11 \\
-0.01 \pm 0.13\end{array}$ & $\begin{array}{l}3 \\
3 \\
3 \\
2\end{array}$ & $\begin{array}{l}83^{c} \\
82 \\
68 \\
50^{c}\end{array}$ \\
\hline Dinoflagellates ${ }^{a, b}$ & $\begin{array}{l}1 \\
2 \\
3 \\
4\end{array}$ & $\begin{array}{l}0.94 \pm 0.16^{\cdots} \cdots \\
1.05 \pm 0.06^{\circ} \\
0.49 \pm 0.14^{*} \\
0.14 \pm 0.23\end{array}$ & $\begin{array}{l}0.94 \pm 0.23 \cdots \\
0.95 \pm 0.09 \cdots \\
0.23 \pm 0.20 \\
0.46 \pm 0.39\end{array}$ & $\begin{array}{l}8 \\
8 \\
7 \\
7\end{array}$ & $\begin{array}{l}0.73 \\
0.95 \\
0.22 \\
0.22\end{array}$ & 1.36 & 1.30 & $\begin{array}{r}0.06 \pm 0.06 \\
0.11 \pm 0.04 \\
0.28 \pm 0.12 \\
-0.29 \pm 0.10\end{array}$ & $\begin{array}{l}3 \\
3 \\
3 \\
2\end{array}$ & $\begin{array}{l}73^{c} \\
61 \\
20 \\
37\end{array}$ \\
\hline Myrionecta rubra & $\begin{array}{l}1 \\
2 \\
3 \\
4\end{array}$ & $\begin{array}{l}0.43 \pm 0.15^{\circ} \\
\text { Not determined } \\
0.51 \pm 0.35 \\
0.06 \pm 0.23\end{array}$ & $\begin{array}{l}0.16 \pm 0.21 \\
0.26 \pm 0.46 \\
0.65 \pm 0.35\end{array}$ & $\begin{array}{l}6 \\
6\end{array}$ & $\begin{array}{l}0.13 \\
0.08 \\
0.46\end{array}$ & & & $\begin{array}{c}0.26 \pm 0.03^{\circ} \\
\text { Not determined } \\
0.22 \pm 0.23 \\
-0.44 \pm 0.02^{\circ}\end{array}$ & $\begin{array}{r}3 \\
3 \\
2\end{array}$ & $\begin{array}{l}23 \\
48\end{array}$ \\
\hline
\end{tabular}

The specific growth rates reached maximum values for flagellates 2 to $10 \mu \mathrm{m}\left(1.97 \mathrm{~d}^{-1}\right)$ in $\mathrm{D} 1$, and diatoms $\left(1.85 \mathrm{~d}^{-1}\right)$ in $\mathrm{D} 2$, but was surpassed by microzooplankton grazing in D2 and D3, respectively, and declined to non-significant values in D4 ( $p>0.05$, Table 3). Emiliania huxleyi specific growth rate peaked later in the bloom (1.91 $\mathrm{d}^{-1}$, in D3), and was not surpassed by microzooplankton grazing in $\mathrm{D} 4$.

Algal specific growth and microzooplankton grazing rates obtained from chl a measurements were within the range of values obtained from cell counts in D2 and D3, whereas rates based on chl a were lower compared to most cell counts in D1 and D4 (Table 3). However, microzooplankton community grazing rates based on chl a were lower than average rates based on cell counts in all 4 experiments. Chl a-based rates were only 47 to $51 \%$ (using regression values only) or 24 to
$50 \%$ (using 3-point values when regression was significantly non-linear) of average rates based on cell counts, when corrected for relative carbon concentration of each algae group, in the 4 experiments.

Net phytoplankton growth measured in the incubation bottles was moderate and generally consistent with the development in the mesocosm (Table 3, Fig. 1B-D). For chl a, Myrionecta rubra and all algae, except Emiliania huxleyi and dinoflagellates, the highest net growth rates were registered in Expts D1 and D2. E. huxieyi net growth was higher compared to all other alga at the beginning of the E. huxleyi bloom (D3), and it was the only species with significant $(p<0.05)$ net growth in D3 and D4.

The addition of nutrients in Expt D5+NP had no clear effect on the algal growth and grazing rate estimates (Table 3), despite the fact that the nitrate concentra- 
tion in the mesocosm was below the detection level (Fig. 1A). Microzooplankton grazing on chl a was not significant ( $p>0.05$ ), and the growth was negative for chl a as well as for Emiliania huxleyi in both series (Table 3). This suggests that factors other than nitratelimitation or microzooplankton grazing were responsible for the decline of the second bloom in the mesocosm.

\section{Copepod feeding}

Calanus finmarchicus cleared the chl a fraction $>10 \mu \mathrm{m}$ at higher rates ( 45 to $71 \mathrm{ml}$ cop. $\mathrm{d}^{-1}$ ) than the 0.45 to $10 \mu \mathrm{m}$ fraction ( $\leq 36 \mathrm{ml}$ cop. $\mathrm{d}^{-} 1$ ) in Expts $\mathrm{C} 1$ to C3 (Table 4), but when Emiliania huxleyi dominated (C4) the fractions were cleared at similar rates $(45$ to $51 \mathrm{ml}$ cop. $\mathrm{d}^{-1}$ ).

Uncorrected copepod feeding rates calculated directly from food concentrations in the experimental bottles according to the original method by Frost (1972) show negative values for particulate chl a 0.45 io î $\mu$ n (signifíicani $p<0.05$ in one case, Tabie 4), fíagellates, Emiliania huxleyi and diatoms (Table 5). Furthermore, while the total food concentration increased from $\mathrm{C} 1$ to $\mathrm{C} 2$ and $\mathrm{C} 3$, the total uncorrected copepod ingestion decreased, and could not account for the observed egg production rate in Expt E1 (Fig. 3). Thus, we corrected the copepod feeding rates according to Eq. (1) and the microzooplankton feeding guilds defined in Table 2, in order to account for the copepod predation on microzooplankton grazers (corrected values, Table 5). Microzooplankton grazing on aplastidic ciliates, dino- and choanoflagellates cannot be measured by the dilution technique. Thus we used the microzooplankton grazing rates derived for plastidic ciliates (Myrionecta rubra), dinoflagellates and 2 to $10 \mu \mathrm{m}$ flagellates (Table 3), for correction of whole spe-

Table 4. Calanus finmarchicus. Feeding experiments $\mathrm{C} 1$ to $\mathrm{C} 4$, chlorophyll (chl) a. Average concentration ( $\mu \mathrm{gl}{ }^{1}$ ), clearance ( $\mathrm{ml}$ ind.$^{-1} \mathrm{~d}^{-1}$ ) and ingestion (ng ind..$^{-1} \mathrm{~d}^{-1}$ ) rates calculated according to Frost $(1972), \pm$ SE for the means. $p<0.05$, $\cdots p<0.01$ for rates $=0(2$-tailed $t$-test $)$

\begin{tabular}{|lccccr|}
\hline $\begin{array}{l}\text { Chl a } \\
\text { fraction }\end{array}$ & $\begin{array}{c}\text { Expt } \\
\text { no. }\end{array}$ & $\begin{array}{c}\text { Average } \\
\text { concentration }\end{array}$ & $\mathrm{n}$ & Clearance & Ingestion \\
\hline $0.45-10 \mu \mathrm{m}$ & 1 & 2.8 & 4 & $36 \pm 12$ & $98 \pm 31^{\circ}$ \\
& 2 & 3.5 & 4 & $-37 \pm 44^{\circ}$ & $-155 \pm 165$ \\
& 3 & 2.3 & 4 & $-15 \pm 5^{\circ}$ & $-36 \pm 11^{\circ}$ \\
& 4 & 10.8 & 3 & $51 \pm 12^{\circ}$ & $549 \pm 19^{\circ}$ \\
$>10 \mu \mathrm{m}$ & 1 & 0.2 & 4 & $71 \pm 12^{*}$ & $12 \pm 2^{\prime}$ \\
& 2 & 8.9 & 4 & $45 \pm 17$ & $390 \pm 141$ \\
& 3 & 3.7 & 4 & $58 \pm 14^{\circ}$ & $210 \pm 46^{\circ}$ \\
& 4 & 5.8 & 3 & $45 \pm 23$ & $255 \pm 124$ \\
\hline
\end{tabular}

cies groups in Table 5 . This does not introduce significant errors, as (1) the contribution of choanoflagellates was only 0 to $20 \%$ of the 2 to $10 \mu \mathrm{m}$ flagellate biomass (Fig. 1), and (2) nauplii and copepodids probably did not change significantly during the incubations (cf. Table 6), and these crustaceans completely dominated the biomass of microzooplankton feeding on dinoflagellates and ciliates (compare Fig. 1 and Table 2). However, as only initial concentrations of nauplii and copepodids were analysed in Expts $\mathrm{C} 1$ and $\mathrm{C} 3$, they were used as average concentrations in Eq. (2).

Corrected total copepod ingestion (Fig 3) increased or remained unchanged when the food concentration increased from C1 to C2, C3 and C4. Corrected ingestion rates were linearly related to average total food concentration $\left(\mathrm{r}^{2}=0.72\right.$, though not significantly, $\mathrm{p}=$ $0.15, n=4$ ), in contrast to uncorrected rates which showed no correlation $\left(\mathrm{r}^{2}=0.01, \mathrm{p}=0.91\right)$. Thus, corrected copepod feeding rates from Table 5 will be referred to below unless otherwise stated.

Calanus finmarchicus preferred ciliates $\geq 30 \mu \mathrm{m}$ in all experiments $(p<0.05$, Table 5$)$, and cleared this food item at significantiy nigner rates compared to the other food types in all experiments ( $p<0.05$, nonparametric multiple contrasts; Zar 1996, p. 229) Ciliates $\geq 30 \mu \mathrm{m}$ made up 1 to $37 \%$ of the ingested carbon, although they never exceeded $16 \%$ of the total average prey carbon. Ciliates $<30 \mu \mathrm{m}$ were not significantly selected,

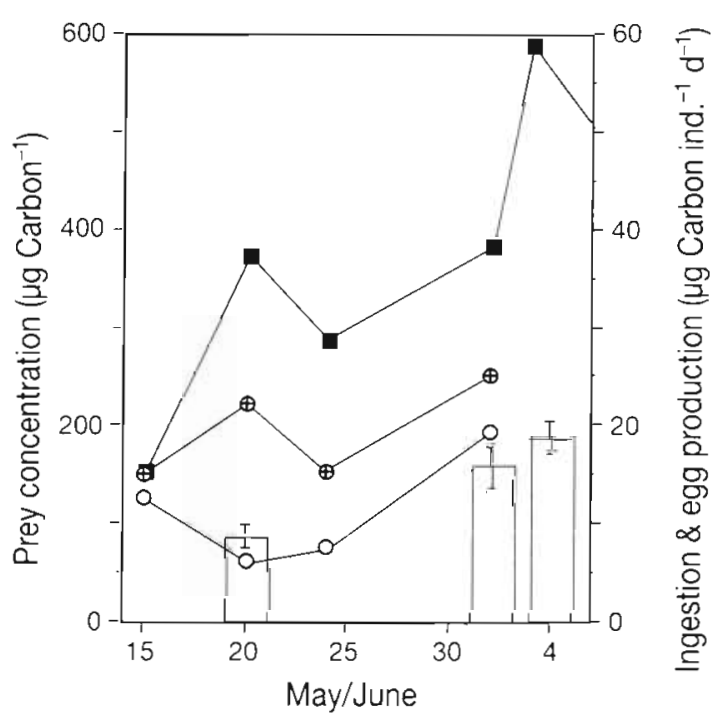

Fig. 3. Calanus finmarchicus. Average prey concentration (- - ) in Expts C1 to C4 (cf. Tables 5 \& 6). ( - - ) Total uncorrected ingestion per copepodid stage $V_{i}(-\infty)$ corrected ingestion. Histograms: average daily egg production by adult females fed water from mesocosm NP1; bars denote SE for the average production from 19 to 21 May (E1, $n=4$ ), for 31 May to 2 June $(E 2 a, n=8)$ and for 3 to 5 June (E2b, $n=8$ ) 
Table 5. Calanus finmarchicus. Feeding experiments $\mathrm{C} 1$ to $\mathrm{C4}$, cell counts. Average prey concentration and uncorrected clearance is calculated according to Frost (1972). Other values are corrected according to Eq. (1) \pm SE for the mean. Prey preference (Manly's alpha) values are multiplied by 100 for convenience, values $>14.3$ indicate preferred food type. $" p<0.05, \cdots p<0.01$, $\cdots p<0.001$ (2-tailed $t$-test) for Clearance and Ingestion $=0$, and Prey preference $=14.3$, respectively

\begin{tabular}{|c|c|c|c|c|c|c|c|c|c|}
\hline \multirow{2}{*}{$\begin{array}{l}\text { Prey type } \\
\text { Ciliates } \geq 30 \mu \mathrm{m}^{a, b}\end{array}$} & $\begin{array}{c}\text { Expt } \\
\text { no. } \\
1\end{array}$ & $\begin{array}{c}\begin{array}{c}\text { Average prey } \\
\text { concentration } \\
\left(\mu \mathrm{C}^{-1}\right)\end{array} \\
0.7\end{array}$ & $\begin{array}{l}\mathrm{n} \\
3^{c}\end{array}$ & \multicolumn{2}{|c|}{$\begin{array}{l}\text { Uncorrected } \\
\text { clearance } \\
\text { (ml ind }{ }^{-1} \mathrm{~d}^{-1} \text { ) }\end{array}$} & \multicolumn{2}{|c|}{$\begin{array}{c}\text { Clearance } \\
\left(\mathrm{ml} \text { ind. }{ }^{-1} \mathrm{~d}^{-1}\right)\end{array}$} & $\begin{array}{c}\text { Corrected values } \\
\text { Ingestion } \\
\left(\mu \mathrm{g} \mathrm{C} \text { ind } .^{-1} \mathrm{~d}^{-1}\right)\end{array}$ & $\begin{array}{c}\begin{array}{c}\text { Prey preference } \\
\text { index }(\times 100)\end{array} \\
25 \pm 2^{-}\end{array}$ \\
\hline & $\begin{array}{l}1 \\
2 \\
3 \\
4\end{array}$ & $\begin{array}{l}0.7 \\
7.8 \\
45 \\
17\end{array}$ & $\begin{array}{l}3^{c} \\
4 \\
4 \\
3\end{array}$ & $\begin{array}{l}280 \pm 19 \\
500 \pm 105 \\
196 \pm 47 \\
191 \pm 7\end{array}$ & $\begin{array}{l}\cdots \\
\dot{*} \\
\cdot\end{array}$ & $\begin{array}{l}280 \pm 190^{\circ} \\
500 \pm 105^{\circ} \\
196 \pm 47 . \\
192 \pm 7\end{array}$ & $\begin{array}{l}\cdots \\
\cdot \\
\cdot\end{array}$ & $\begin{array}{l}0.1 \pm 0.0^{\cdots} \cdots \\
1.6 \pm 0.1 \cdots \\
5.4 \pm 1.0^{\circ} \\
2.3 \pm 0.1 \cdots\end{array}$ & $\begin{array}{l}25 \pm 2 \\
40 \pm 6 \\
43 \pm 8^{\circ} \\
44 \pm 4\end{array}$ \\
\hline Ciliates $<30 \mu \mathrm{m}^{\text {b.d }}$ & $\begin{array}{l}1 \\
2 \\
3 \\
4\end{array}$ & $\begin{array}{l}30 \\
39 \\
39 \\
18\end{array}$ & $\begin{array}{l}4 \\
4 \\
4 \\
3\end{array}$ & $\begin{aligned} 180 & \pm 28 \\
144 & \pm 40 \\
34 & \pm 17 \\
35 & \pm 7\end{aligned}$ & $\begin{array}{l}\ddot{\cdot} \\
\cdot\end{array}$ & $\begin{array}{c}180 \pm 28 \\
144 \pm 40^{\circ} \\
35 \pm 17 \\
36 \pm 7\end{array}$ & $\begin{array}{l}\cdots \\
\cdot\end{array}$ & $\begin{array}{l}3.9 \pm 0.3 \cdots \\
4.3 \pm 1.0^{\circ} \\
1.2 \pm 0.6 \\
0.6 \pm 0.1\end{array}$ & $\begin{array}{l}15 \pm 1 \\
20 \pm 4 \\
11 \pm 4 \\
11 \pm 3\end{array}$ \\
\hline Diatoms & $\begin{array}{l}1^{e} \\
2 \\
3 \\
4^{e}\end{array}$ & $\begin{array}{c}9.1 \\
168 \\
100 \\
59\end{array}$ & $\begin{array}{l}4 \\
4 \\
4 \\
3\end{array}$ & $\begin{aligned} 161 & \pm 5 \\
4 & \pm 28 \\
-28 & \pm 26 \\
15 & \pm 36\end{aligned}$ & $\cdots$ & $\begin{aligned} 180 & \pm 3 \\
85 & \pm 22 \\
73 & \pm 20 \\
36 & \pm 37\end{aligned}$ & $\cdot$ & $\begin{array}{c}1.0 \pm 0.1 \cdots \\
14.0 \pm 3.1{ }^{\circ} \\
7.1 \pm 1.7 \\
1.9 \pm 2.0\end{array}$ & $\begin{aligned} 12 & \pm 1 \\
16 & \pm 5 \\
25 & \pm 3 \\
9 & \pm 5\end{aligned}$ \\
\hline Dinoflagellates' & $\begin{array}{l}1^{\mathrm{e}} \\
2 \\
3 \\
4\end{array}$ & $\begin{array}{l}1.1 \\
6.0 \\
17 \\
21\end{array}$ & $\begin{array}{l}4 \\
4 \\
4 \\
3\end{array}$ & $\begin{array}{l}75 \pm 23 \\
64 \pm 17 \\
30 \pm 5 \\
21 \pm 16\end{array}$ & $\cdot$ & $\begin{array}{l}75 \pm 24 \\
64 \pm 12 \\
30 \pm 5 \\
22 \pm 16\end{array}$ & $\dot{.}$ & $\begin{array}{l}0.1 \pm 0.0^{\circ} \\
0.3 \pm 0.0^{\circ} \\
0.4 \pm 0.1 \\
0.4 \pm 0.3\end{array}$ & $\begin{array}{l}7 \pm 3 \\
9 \pm 1 \\
8 \pm 1 \\
5 \pm 3\end{array}$ \\
\hline Flagellates $\geq 10 \mu \mathrm{m}$ & $\begin{array}{l}1 \\
2 \\
3 \\
4\end{array}$ & $\begin{array}{r}83 \\
108 \\
37 \\
20\end{array}$ & $\begin{array}{l}4 \\
4 \\
4 \\
3\end{array}$ & $\begin{array}{r}84 \pm 25 \\
-13 \pm 68 \\
-41 \pm 15 \\
-54 \pm 80\end{array}$ & & $\begin{array}{r}91 \pm 24 \\
15 \pm 66 \\
-13 \pm 14 \\
-28 \pm 82\end{array}$ & & $\begin{array}{l}6.9 \pm 1.5^{\circ} \\
0.0 \pm 7.0 \\
- \\
-\end{array}$ & $\begin{array}{c}10 \pm 2 \\
0 \pm 0 \cdots \\
0 \\
0\end{array}$ \\
\hline Emiliania huxleyi & $\begin{array}{l}1 \\
2 \\
3 \\
4^{\mathrm{e}}\end{array}$ & $\begin{array}{c}0.8 \\
2.8 \\
16 \\
203\end{array}$ & $\begin{array}{l}4 \\
4 \\
4 \\
3\end{array}$ & $\begin{array}{r}46 \pm 58 \\
-110 \pm 84 \\
-47 \pm 59 \\
85 \pm 18\end{array}$ & & $\begin{array}{r}139 \pm 70 \\
-43 \pm 91 \\
12 \pm 59 \\
110 \pm 18 .\end{array}$ & & $\begin{array}{c}0.1 \pm 0.0 \\
0.0 \pm 1.1 \\
19.0 \pm 2.7\end{array}$ & $\begin{array}{l}12 \pm 5 \\
0 \\
0 \pm 0 \cdots \\
30 \pm 1 \cdots\end{array}$ \\
\hline Flagellates $2-10 \mu \mathrm{m}^{9}$ & $\begin{array}{l}1 \\
2 \\
3 \\
4^{e}\end{array}$ & $\begin{array}{l}20 \\
24 \\
14 \\
18\end{array}$ & $\begin{array}{l}4 \\
4 \\
4 \\
3\end{array}$ & $\begin{aligned} 84 & \pm 24 \\
-3 & \pm 38 \\
-15 & \pm 44 \\
-60 & \pm 106\end{aligned}$ & & $\begin{array}{c}190 \pm 34 \\
96 \pm 39 \\
41 \pm 40 \\
12 \pm 112\end{array}$ & & $\begin{array}{l}3.1 \pm 0.5 \cdots \\
2.1 \pm 0.8 \\
0.5 \pm 0.6 \\
0.0 \pm 2.1\end{array}$ & $\begin{aligned} 18 & \pm 2 \\
16 & \pm 6 \\
12 & \pm 8 \\
0 & \pm 0 \cdots\end{aligned}$ \\
\hline $\begin{array}{l}\text { 'Including predatory } \\
\text { carbon) } \\
\text { 'Rates corrected using } \\
\text { cients of Myrionecta } \\
\text { 'One parallel omitted } \\
\text { and ingestion rates, } \\
\text { mean ingestion rate } \\
\text { the fourth parallel }\end{array}$ & $\begin{array}{l}\text { species } \\
\text { g micro } \\
\text { rubra } \\
\text { due to } \\
\text { while ir } \\
\text { was use }\end{array}$ & $\begin{array}{l}\text { in C4 ( } 15 \% \text { of } \geq \\
\text { zooplankton gra } \\
\text { zero count, } n=3 \\
\text { prey preference } \\
\text { d as a minimum }\end{array}$ & $\begin{array}{l}\text { ar cl } \\
\text { alcu } \\
\text { time }\end{array}$ & $\begin{array}{l}\text { iliate } \\
\text { fi- } \\
\text { rance } \\
\text { eons } \\
\text { e of }\end{array}$ & $\begin{array}{l}{ }^{d} \text { Inc } \\
{ }^{e} \mathrm{Rat} \\
\text { cie } \\
\text { bas } \\
{ }^{1} \mathrm{Ce} \\
{ }^{9} \mathrm{Ch} \\
\text { car }\end{array}$ & $\begin{array}{l}\text { ng } M \text {. rubra } \\
\text { orrected usin } \\
\text { obtained from } \\
\text { on linear regr } \\
\text { im spp. are pr } \\
\text { oflagellates ir } \\
\text { ) }\end{array}$ & $\begin{array}{l}\text { ng } n \\
\text { m th } \\
\text { gress } \\
\text { orese } \\
\text { incle }\end{array}$ & $\begin{array}{l}\text { nicrozooplankton } g \\
\text { e } 3 \text {-point method; } \\
\text { ion including all } d \\
\text { ented separately in } \\
\text { uded }(\leq 20 \% \text { of } 2-\end{array}$ & $\begin{array}{l}\text { grazing coeffi- } \\
\text { all others are } \\
\text { lata points } \\
\text { Table } 6 \\
-10 \mu \mathrm{m} \text { flagellate }\end{array}$ \\
\hline
\end{tabular}

but were still cleared at relatively high rates and made up a substantial part of the food intake ( 2 to $26 \%$ ). Diatoms (mainly Skeletonema costatum) were selected prey in C3, and constituted 48 to $62 \%$ of the diet in C2 and C3. However, when diatoms were less abundant and dominated by the pennate Pseudonitzschia sp. (C4), they were not preferred. Emiliania huxleyi was avoided in the first experiments, but was selected and made up $74 \%$ of the ingested carbon in C4 when it dominated the phytoplankton. This change in diet was reflected in the composition of the copepod faecal pellets. Pellets examined in a light microscope from C2 and $\mathrm{C} 3$ were greenish-brownish and pellucid, whereas pellets from $\mathrm{C} 4$ were opaque and appeared densely packed with a white substance. Pellets analysed with SEM from C4 consisted mainly of coccoliths, in contrast to $C 3$ where coccoliths were virtually absent. Flagellates were never significantly selected, although flagellates $\geq 10 \mu \mathrm{m}$ made up about half of the diet in $\mathrm{C} 1$ (Table 5). Neither cell counts (Table 6) nor microscopic analysis of cell contents of Ceratium spp. indicated copepod predation. Rotifers were cleared at high rates (ca $100 \mathrm{ml}$ copepod $\mathrm{d}^{-1} \mathrm{~d}^{-1}$ ), but made up only 0 to $3 \%$ of the potential prey carbon, and contributed $<4 \%$ to the copepod diet (Table 6). Nauplii were not ingested by C. finmarchicus (Table 6). 
Table 6. Calanus finmarchicus. Feeding experiments $\mathrm{C} 1$ to $\mathrm{C} 4$, larger prey types. Only initial prey concentrations were sampled in C1 and C3. Average prey concentration, clearance and ingestion rates were calculated according to Frost (1972). Prey preference index was calculated including values from Table $5 ;$ thus values $>11$ indicate preferred food type. \pm SE for the mean $\cdot p<0.05$ (2-tailed $t$-test) for Clearance and Ingestion $=0$, and Prey preference $=11$, respectively

\begin{tabular}{|c|c|c|c|c|c|c|}
\hline Prey type & $\begin{array}{c}\text { Expt } \\
\text { no. }\end{array}$ & $\begin{array}{l}\text { Average prey } \\
\text { concentration } \\
\left(\mu \mathrm{g} \mathrm{Cl}^{-1}\right)\end{array}$ & $n$ & $\begin{array}{c}\text { Clearance } \\
\left(\mathrm{ml} \text { ind } .^{-1} \mathrm{~d}^{-1}\right)\end{array}$ & $\begin{array}{c}\text { Ingestion } \\
\left(\mu \mathrm{g} \mathrm{C} \text { ind }{ }^{-1} \mathrm{~d}^{-1}\right)\end{array}$ & $\begin{array}{l}\text { Prey preference } \\
\text { index }(\times 100)\end{array}$ \\
\hline Nauplii & $\begin{array}{l}1 \\
2 \\
3 \\
4\end{array}$ & $\begin{array}{l}1.9 \\
3.6 \\
2.3 \\
5.0\end{array}$ & 4 & $\begin{array}{c}-8 \pm 21 \\
-36 \pm 36\end{array}$ & - & $\begin{array}{l}0 \\
0\end{array}$ \\
\hline Rotifers & $\begin{array}{l}1 \\
2^{b} \\
3 \\
4\end{array}$ & $\begin{array}{l}0.0 \\
0.3 \\
2.8 \\
10\end{array}$ & 4 & $\begin{array}{c}100 \\
106 \pm 24^{\circ}\end{array}$ & $\begin{array}{c}0.0 \\
0.9 \pm 0.2\end{array}$ & $\begin{array}{c}11 \\
23 \pm 6^{\circ}\end{array}$ \\
\hline Ceratium spp. & $\begin{array}{l}1 \\
2 \\
3 \\
4\end{array}$ & $\begin{array}{l}0.1 \\
0.1 \\
0.2 \\
0.05\end{array}$ & 4 & $\begin{array}{r}20 \pm 35 \\
-32 \pm 52\end{array}$ & $\begin{array}{c}0.0 \pm 0.0 \\
-\end{array}$ & $\begin{array}{c}4 \pm 4 \\
0\end{array}$ \\
\hline
\end{tabular}

\section{Daily copepuả food rations, egg and íaecal peỉet production}

Egg and faecal pellet production by females incubated in suspensions of the reference alga Rhodomonas baltica did not vary significantly $(p=0.93$, single factor ANOVA; Zar 1996, p. 180-183) between the experimental periods E1, E2a and E2b (Table 7). This indicates that the physiological condition of the females was comparable between the periods, and not influenced by change in experimental conditions. During the Emiliania huxleyi bloom (E2a) the faecal pellets were smaller (or possibly more often broken), but more numerous than during the diatom/flagellate bloom (E1) in NP1. In terms of volume, however, faecal egestion was similar between the 2 blooms, which is in accordance with the corrected ingestion rates (Table 7 ). In contrast, females produced significantly more eggs when they were incubated in water from the E. huxleyi bloom in NP1 (Table 7. E2a and b), compared to when they were incubated in the diatom-dominated food suspensions from NPS1 at similar total food (nitrogen) concentrations ( $p<0.05$ and $<0.01$ in E2a and E2b, respectively, Sheffé's test; Zar 1996, p. 222-225). Also, by the termination of the mesocosms the mesozooplankton and Calanus finmarchicus biomass had increased ca 3 times more in mesocosms dominated by E. huxleyi blooms (NP1 and NP2), compared to mesocosms with mainly diatom blooms (NPS1 and NPS2, Table 8). Unfortunately we do not know the development of the microzooplankton in the NP2 or the NPS mesocosms, but the average algal biomass (in terms of particular nitrogen) was similar in aii mesocosms, while primary production was ca 2 times higher in the NPS mesocosms (Egge \& Jacobsen 1997). Thus the lower egg production rates in the diatom-dominated NPS mesocosms cannot be explained by a lower total food concentration.

A conversion of egg production rates into carbon production in NP1 water during E1 $(8.5 \pm 2.3 \mu \mathrm{g} \mathrm{C}$ ind.$\left.^{-1} \mathrm{~d}^{-1}\right)$ and E2a $\left(15.3 \pm 3.3 \mu \mathrm{g} \mathrm{C}\right.$ ind.$\left.^{-1} \mathrm{~d}^{-1}\right)$ indicated either unrealistically high gross growth efficiencies of 137 and $79 \%$, respectively, using uncorrected ingestion rates, or gross growth efficiencies of 38 and $61 \%$, using corrected ingestion rates. The corresponding growth efficiencies based on nitrogen (Table 7) were 162 and $82 \%$ for uncorrected rates and 42 and $65 \%$ for corrected rates, respectively. This implies that uncorrected ingestion rates severely underestimate the true ingestion rates, and that the conversion of food into egg production by the copepod may have been significantly less efficient during the diatom/flagellate bloom, compared to the Emiliania huxleyi bloom, based on the corrected ingestion rates.

\section{Copepod feeding effects on plankton development}

Calculation of direct predation impact by late copepodids of Calanus finmarchicus on the plankton community in the NP1 mesocosm from ingestion rates in Tables $5 \& 6$ yielded insignificant values for all prey categories other than perhaps ciliates $\geq 30 \mu \mathrm{m}$. Assuming an average abundance of $0.32 \mathrm{C}$. finmarchicus 


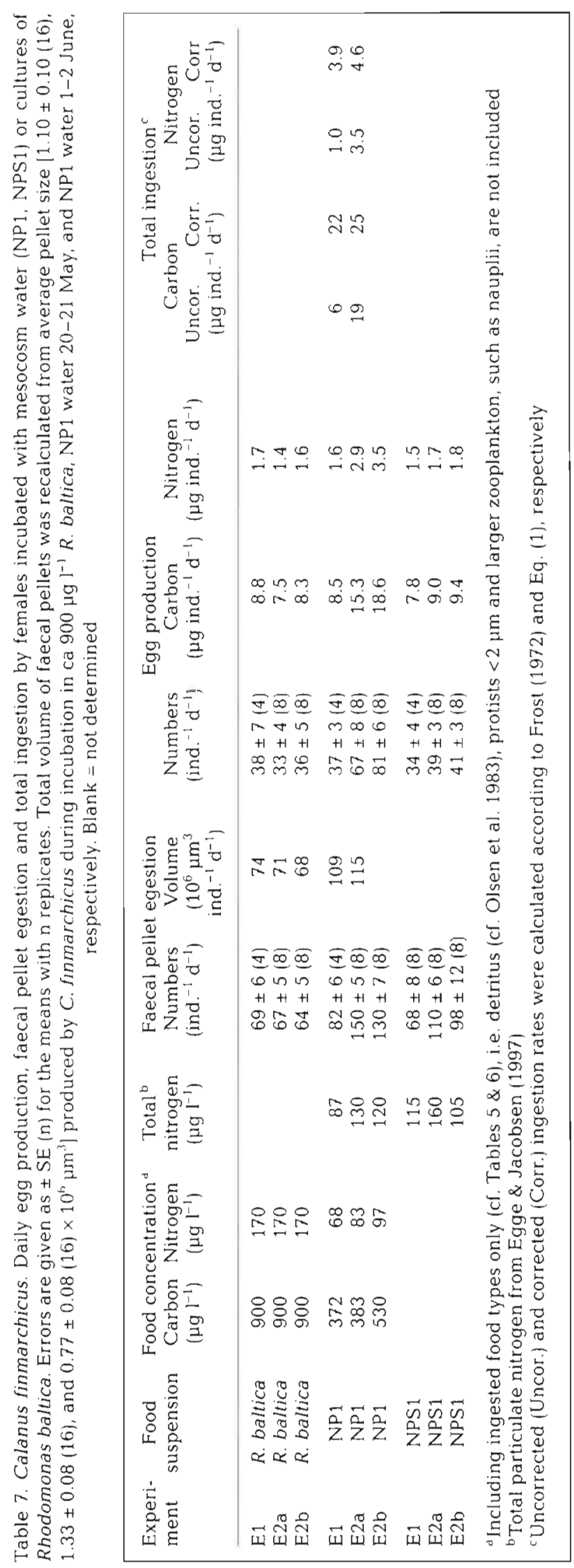

Table 8. Calanus finmarchicus. Biomass ( $\mu \mathrm{g}$ carbon $\mathrm{l}^{-1}$ ) of copepodids and total mesozooplankton in the mesocosms

\begin{tabular}{|lcccc|}
\hline Mesocosm & \multicolumn{2}{c}{$\begin{array}{c}\text { C. finmarchicus } \\
\text { 15 May }\end{array}$} & 20 June & \multicolumn{2}{c|}{ Total mesozooplankton } \\
& & & & \\
& 12 & 71 & 19 & 20 June \\
NP1 & 12 & 76 & 17 & 107 \\
NP2 & 25 & 37 & 29 & 46 \\
NPS1 & 10 & 22 & 17 & 33 \\
NPS2 & & & & \\
& & & &
\end{tabular}

$\mathrm{CV} \mathrm{l}^{-1}$ in NP1, equivalent to ca $60 \mu \mathrm{g}$ copepod carbon $\mathrm{I}^{-1}$. suggests a daily turnover of the average standing stock of 4.5 to $7 \%$ for ciliates $\geq 30 \mu \mathrm{m}$, compared to 0 to $4.5 \%$ for all others. As the total abundance of copepods in the NP1 mesocosm increased from ca 20 to $60 \mathrm{\mu g} \mathrm{C} \mathrm{I}^{-1}$, between 15 May and 13 June (Fig. 1H), this may be viewed as a maximum estimate. However, the presence of $4 \mathrm{C}$. finmarchicus $\mathrm{CV} \mathrm{l}^{-1}$ in $200 \mu \mathrm{m}$ pre-screened mesocosm water strongly affected the algal and ciliate succession in Expt L1 (Fig. 4). The biomass of all ciliates and chl $a>10 \mu \mathrm{m}$ was strongly suppressed compared to the blank, while chl a 0.45 to $10 \mu \mathrm{m}$ increased by 2 to 3 times compared to the blank. Ciliates $\geq 30 \mu \mathrm{m}$ were also strongly reduced in bottles with $1 \mathrm{CV} \mathrm{l}^{-1}$. while small ciliates and algae were much less affected. The development of Emiliania huxleyi, flagellates 2 to $10 \mu \mathrm{m}$ and diatoms was reflected in the development of chl a.

During the $4 \mathrm{~d}$ incubation run a week later (L2), large predatory ciliates and rotifers increased to high concentrations in the blank, while their increases were significantly reduced in treatments with 1 Calanus $\mathrm{CV}^{-1}$ (Fig. 5). As in L1, large non-predatory ciliates were reduced compared to the blank in treatments with ca 1 Calanus $\mathrm{CV} \mathrm{l}^{-1}$, but ciliates $<30 \mu \mathrm{m}$ were not. $\mathrm{Chl} a$ followed the same pattern compared to the blank as in L1, while the development of chl $a$ and ciliates in the control bottles compared to initial values were different, as there was only modest growth of large algae, and the concentration of non-predatory ciliates fell considerably. The increase in predatory ciliates and rotifers was in concert with the development in the mesocosm, and may explain the decrease of nonpredatory ciliates. Algae were only analysed in initial samples from Expt L2. Algae $>10 \mu \mathrm{m}$ were then mainly diatoms ( $74 \%$ in terms of carbon) and plastidic dinoflagellates $(21 \%)$. The 0.45 to $10 \mu \mathrm{m}$ fraction was dominated by Emiliania huxleyi and undetermined flagellates 5 to $10 \mu \mathrm{m}$ ( 55 and $44 \%$ of the carbon, respectively). It is likely that the increase in chl a 0.45 to $10 \mu \mathrm{m}$ during $\mathrm{L} 2$ reflects an increase in E. huxleyi, as this was the only species which showed significant net growth (Table 3 ) and increased in the mesocosm at this time (Fig. 1C, D). 


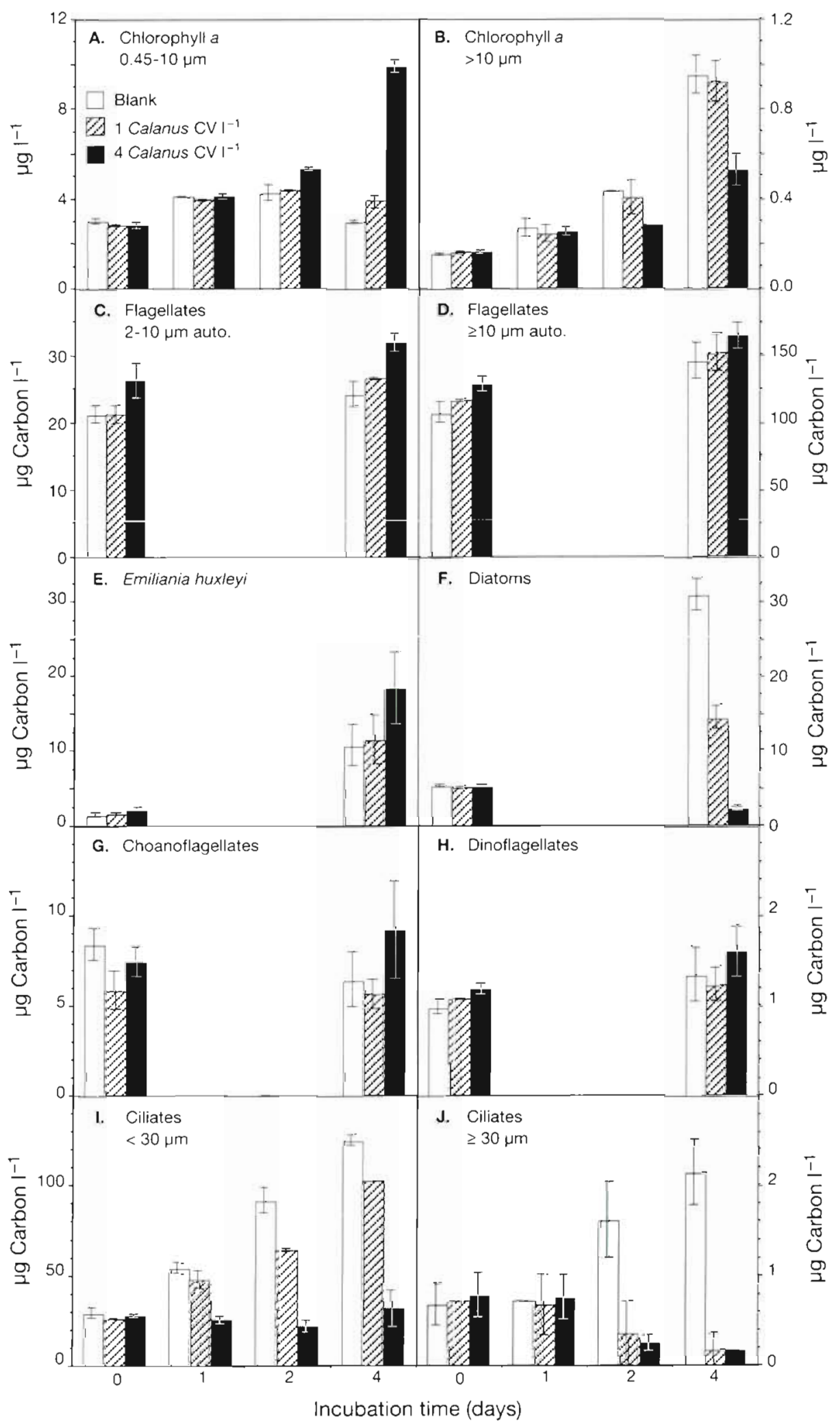

Fig. 4. Expt L1 Plankton development between 15 and 19 May. (A) Chlorophyll a 0.45 to $10 \mu \mathrm{m}$. (B) Chlorophyll a $>10 \mu \mathrm{m}$. (C) Flagellates 2 to $10 \mu \mathrm{m}$ (choanoflagellates excluded). (D) Flagellates $\geq 10 \mu \mathrm{m}$ were mainly between 10 and $15 \mu \mathrm{m}$. (E) Emiliania huxleyi. (F) Diatoms. (G) Choanoflagellates. (H) Dinoflagellates. (I) Ciliates $<30 \mu \mathrm{m}$. (J) Ciliates $\geq 30 \mu \mathrm{m}$. Bars denote ranges $(\mathrm{n}=2)$. In (C) to $(\mathrm{H})$ samples from Days 1 and 2 were not analysed 


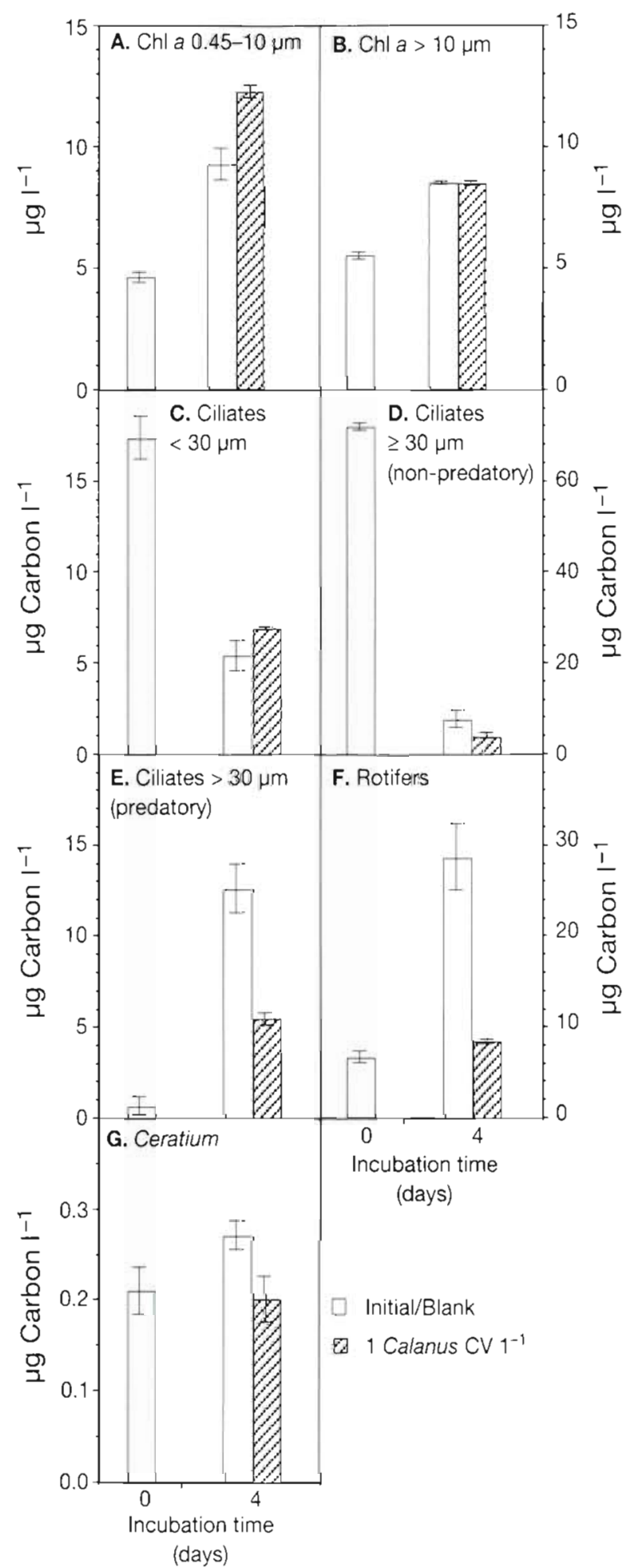

Fig. 5. Expt L2. Plankton development between 27 and 31 May. (A) Chlorophyll a 0.45 to $10 \mu \mathrm{m}$. (B) Chlorophyll a $>10 \mu \mathrm{m}$. (C) Ciliates $<30 \mu \mathrm{m}$. (D) Ciliates $\geq 30 \mu \mathrm{m}$ (non-predatory). (E) Predatory ciliate species are cf. Monodium sp., cf. Cyclotrichum sp. and cf. Acineta sp. (F) Rotifers. (G) Ceratium are $C$. longipes and $C$. tripos. Bars denote ranges $(\mathrm{n}=2)$

\section{DISCUSSION}

\section{Extrapolation of results from mesocosms to field situations}

Compared to laboratory experiments, sea water enclosures offer a more realistic environment with a larger volume and inclusion of a higher number of trophic levels. However, advective processes are excluded, and other bag effects such as accelerated plankton succession may also be important (Davis 1982, cited in Egge 1993). Thus caution should be exercised when extrapolating mesocosm data to the field. However, similar in situ sea water enclosure experiments conducted in western Norway during the last decade have showed relatively small differences between untreated control enclosures and the surrounding water on the development of phytoplankton and ciliates. In contrast, experimentally treated enclosures generally have shown much stronger signals with similar development in parallels (Dale 1988, Egge 1993, Egge \& Jacobsen 1997).

Important algae and zooplankton genera found in the mesocosm experiments were similar to those observed in Norwegian fjords and coastal waters (e.g. Birkenes \& Braarud 1952, Wiborg 1954, Erga \& Heimdal 1984, Dale 1988). Diatoms and Emiliania huxleyi reached high abundances during this experiment $\left(3.5 \times 10^{6}\right.$ and $2.5 \times 10^{7}$ cells $l^{-1}$, respectively). This is within the higher end of bloom concentrations reported from the Norwegian coast $\left(\leq 7.0 \times 10^{6}\right.$ diatoms $\mathrm{I}^{-1}$ and $\leq 1.1 \times 10^{8}$ E. huxleyi $\mathrm{l}^{-1}$, respectively; Birkenes $\&$ Braarud 1952, Berge 1962, Erga 1989). Maximum ciliate abundance in mesocosm NP1 were ca 2 to 5 times higher than normally encountered during natural blooms in coastal waters (Smetacek 1981, Erga \& Heimdal 1984, Nielsen \& Kiørboe 1994). However, ciliates like Lohmaniella oviformis, which dominated the ciliate peak biomass, may reach such high abundances $\left(>1 \times 10^{5} 1^{-1}\right)$ when conditions are favourable (Andersen \& Sørensen 1986). Nonetheless, the high ciliate concentrations cannot explain the difference in Calanus finmarchicus egg production rates observed in E1 and E2a, respectively (Table 7 ), as average ciliate biomass and copepod ingestion rates of ciliates were 1.3 and 2 times higher, respectively, during the first of the corresponding grazing experiments ( $\mathrm{C} 2$ and $\mathrm{C} 4$, Table 5).

The abundance of mesozooplankton was also relatively high in the mesocosms, but within the range of concentrations reported from Norwegian coastal waters (Wiborg 1954). Larger zooplanktivores such as fish and medusa were absent in all mesocosms. This may partly explain the high mesozooplankton numbers, but cannot explain the 3 times larger increase in mesozooplankton biomass in both the NP mesocosms, compared to the NPS mesocosms. 


\section{Growth and grazing rate estimations, methodology}

Algal specific growth rates obtained from chl a measurements were generally lower than rates based on cell counts, and chl a-based microzooplankton grazing rates were $\leq 51 \%$ of rates based on cell counts. Similarly, Waterhouse \& Welschmeyer (1995) showed that microzooplankton grazing rates based on chl a were on average only $52 \%$ of the true grazing rates obtained from direct cell counts in a series of laboratory experiments. In Expt D4 there was also a large discrepancy between the chl a net growth and the net growth recorded for Emiliania huxleyi, which then dominated the autotrophic carbon. A similar trend was recorded in the NP1 mesocosm, where the autotrophic carbon increased between 1 and 3 June, while the total chl a concentration dropped by $>40 \%$ (Egge \& Jacobsen unpubl. data). This may be explained by a decrease in chl a content per cell. Decreases in chl a concentrations during blooms of $E$, huxleyi have previously been registered (e.g. Wal et al. 1994). Thus we conclude that pigment based rates may be viewed as minimai estimates and we focus on the resuits from ceij counts in the following discussion.

Cell counts yielded very high specific growth rates ( $\mu$ ) for Emiliania huxleyi, 2 to $10 \mu \mathrm{m}$ flagellates and diatoms dominated by Skeletonema costatum in Expts D1 to D3 (ca $1.9 \mathrm{~d}^{-1}$ ). These rates appear to be near the limit for absolute algae growth at $10^{\circ} \mathrm{C}$ (cf. Chisholm 1992), and match the maximal specific growth rate $\left(\mu_{\max }\right)$ of $1.9 \mathrm{~d}^{-1}$ reported for laboratory cultures of S. costatum (Sakshaug \& Andresen 1986, recalculated from $2.5 \mathrm{~d}^{-1}$ at $15^{\circ} \mathrm{C}$ using a $Q_{10}$ of 1.88 from Chisholm 1992). Other studies based on the dilution technique report chl a $\mu_{\max }$ of $1.60 \pm 0.08 \mathrm{~d}^{-1}( \pm \mathrm{SD}, \mathrm{n}=8$ ) during a bloom of $S$. costatum at $13^{\circ} \mathrm{C}$ (Andersen et al. 1991), and phytoplankton community growth rates up to 1.73 $\pm 0.30 \mathrm{~d}^{-1}( \pm 95 \% \mathrm{Cl})$ at $10^{\circ} \mathrm{C}$ when the chl a was dominated by plankton $<20 \mu \mathrm{m}$ (Neuer \& Knowles 1994). Both these rates are considerably higher than the highest $\mu$ for chl a obtained here $\left(1.22 \pm 0.04 \mathrm{~d}^{-1} \pm \mathrm{SE}\right.$, $\mathrm{n}=8$ ), and the $\mu$ for the small flagellates and diatoms in our study does not appear to be significantly different from the 2 rates presented above, despite the fact that results based on pigments are expected to underestimate the true rates. However, E. huxleyi is reported to have growth rates of less than $1.0 \mathrm{~d}^{-1}$ at temperatures around $10^{\circ} \mathrm{C}$, while specific rates of 1.3 to $1.4 \mathrm{~d}^{-1}$ (at 14 to $16^{\circ} \mathrm{C}$ ) and $1.85 \mathrm{~d}^{-1}$ (at $26^{\circ} \mathrm{C}$ ) have been found under lab conditions (Brand 1982, Bleijswijk \& Veldhuis 1995, E. Paasche, Univ, Oslo, pers. comm). Thus it seems that the specific growth rate for E. huxleyi in D1 to D3 may be overestimated. It should however be noted that microzooplankton grazers were not included in the lab studies referred to above, and it has been shown that microzooplankton grazing activities may enhance in situ pico-and nanoplankton specific growth by a factor of 2 to $>10$ compared to growth rates without the presence of protozoa (Ferrier \& Rassoulzadegan 1991). Ferrier-Pagès \& Rassoulzadegan (1994) reported in situ nanoplankton specific growth rates in the Mediterranean between 0.8 and $1.2 \mathrm{~d}^{-1}$ when the microzooplankton was removed, whereas in the presence of microzooplankton it was 1.4 to 2.8 times higher $(1.6$ to $2.2 \mathrm{~d}^{-1}$ ) during periods with nitrate, phosphate and silicate concentrations of 0.17 to $0.26,0.12$ to 0.34 and 1.1 to $1.6 \mu \mathrm{mol} \mathrm{l^{-1 }}$, respectively, water temperature of $13^{\circ} \mathrm{C}$, and much lower ciliate concentrations $(1.3$ to $3.5 \times$ $10^{3}$ cells $\mathrm{l}^{-1}$ ) than found during D1 to D3.

\section{Microzooplankton grazing and development}

The microzooplankton had a significant grazing impact on the phytoplankton in the NP1 mesocosm, about one order of magnitude higher than the grazing pressure exerted by copepods. This is in accordance with previous studies from coastal and oceanic waters, which have repeatedly shown the importance of microzooplankton as grazers on the phytoplankton (e.g. Pierce \& Turner 1992, Banse 1995, and references therein]. The abundance of small phytoflagellates was kept low in the mesocosm, despite high growth rates, and in the $4 \mathrm{~d}$ incubations abundance of 2 to $10 \mu \mathrm{m}$ flagellates was negatively correlated to abundance of non-predatory microzooplankters, indicating microzooplankton grazing control of these algae. This is in accordance with previous studies (e.g. Kivi et al. 1993, 1996). However, Skeletonema costatum were also grazed at high rates during the first 3 experiments while the pennate diatom Pseudonitzschia sp., which dominated the diatoms during the second bloom, was grazed at lower rates. Diatoms are generally thought to escape microzooplankton grazing due to large cell size and chain formation (e.g. Burkill et al. 1987). However, the cell size of $S$. costatum was relatively small $(5 \mu \mathrm{m} \times$ $14 \mu \mathrm{m})$ and larger microzooplankton, such as ciliates $\geq 30 \mu \mathrm{m}$, may crop single diatoms cells from the end of the chains (Per Jonsson, University of Gothenburg, pers. comm.).

During the first experiment the abundance of larger microzooplankton was low, and diatoms increased rapidly. This may explain the indication of food satiation of the microzooplankton feeding on the largest phytoplankton (dinoflagellates and diatoms) in Expt D1, and the rapid growth of larger ciliates during D2 to D3. In D3 microzooplankton grazing surpassed the diatom specific growth rate, and although the microzooplankton grazing rate declined in D4, the diatom net growth was still negative. Thus, it seems probable that the 
diatom-dominated bloom stimulated growth of larger microzooplankton, and later became grazer-controlled.

Emiliania huxleyi was grazed at much lower rates than the similar sized small phytoflagellates in 3 out of 4 cases. In contrast to other algae E. huxleyi specific growth rates were never surpassed by microzooplankton grazing. Furthermore, during the E. huxleyi bloom the microzooplankton composition changed and decreased, and the daily turnover of diatoms and E. huxleyi fell to ca 50\% compared to maximum values. Heterotrophic dinoflagellates was the only group of microzooplankton that did not decrease during the E. huxleyi bloom. Although dinoflagellates such as Oxhyrris marina may ingest monocultures of E. huxleyi, it was not a preferred food in mixed food algae suspensions (Hansen et al. 1996, Wolfe \& Steinke 1996). Dinoflagellates also have a higher persistence during periods of unfavourable food conditions compared to e.g. ciliates (Hansen 1992), and the grazing pressure from both Calanus finmarchicus and microzooplankton was low. Thus we conclude that $E$. huxleyi did not support growth of most microzooplankters, and microzooplankton grazing was not responsible for the decline of the E. huxleyi bloom in the NP1 mesocosm. In contrast, selective grazing by the microzooplankton on other species may have facilitated the bloom of $E$. huxleyi.

\section{Satiated microzooplankton feeding}

The microzooplankton feeding responses were nonlinear in Expt D1 and 4. Such results may arise when the microzooplankton community grazing is saturated at high food concentrations (Gallegos 1989) and/or when nutrients are limiting (Andersen et al. 1991). In D1 the nutrient levels were high and the microzooplankton was probably saturated for diatoms and dinoflagellates as discussed above, whereas nitrogen limitation may have contributed to the non-linear responses in D4, as the nitrate level was below detection at this time.

Addition of nutrients to D5 affected neither growth nor grazing rates. The results of the dilution experiments reflect the culmination of the Emiliania huxleyi bloom in the NP1 mesocosm. It is likely that the insignificant chl a grazing rates obtained reflected a true low microzooplankton grazing upon the dominating E. huxleyi.

\section{Copepod feeding}

Copepod feeding rates calculated directly from algae and chl a concentrations in the experimental bottles frequently show negative values. This is theoretically impossible and we argue that this is an artefact due to the selective predation by the copepods upon the microzooplankton, releasing the high microzooplankton grazing pressure on the phytoplankton which masks the simultaneous but weaker copepod grazing effect on the phytoplankton during the incubation. Eq. (1) represents a simplified method to correct for this artefact. It is, however, well known that microzooplankters may feed selectively, or may be constrained by size limits of the prey, or both (see references in Table 2). To account for this we assigned the different microzooplankters to functional feeding guilds, mainly based on prey-size limitations (Table 2). But, for simplicity we assumed no feeding selectively or difference in species-specific ingestion rates within each guild. However, ciliates generally show higher specific ingestion rates compared to other microzooplankters such as dinoflagellates, nauplii and copepodids (Hansen 1992, Gismervik et al. in press). Thus, when the copepods selectively ingest ciliates, as in this study, the correction by Eq. (1) should be considered conservative. Nevertheless, most of the negative uncorrected rates were accounted for by Eq. (1), and corrected rates, in contrast to uncorrected, gave a trustworthy relation between ingestion rate, on the one hand, and food concentration, egg production as well as faecal pellet volume production rate, on the other hand.

Lack of corresponding adjustments for copepod grazing on microzooplankton in previous studies may have lead to a substantial underestimation of in situ grazing and food selectivity on smaller phytoplankton by copepods.

Calanus finmarchicus copepodids showed significant preference for large ciliates in all experiments. Various field studies have concluded that Calanus spp. prefer ciliates (Kleppel 1993, Fessenden \& Cowles 1994, Nejstgaard et al. 1994, Atkinson 1996, and references therein), and have shown clearance rates in the same range as in this study. It has been speculated that ciliates may be of greater nutritional value than algae (Stoecker \& Capuzzo 1990, Sanders \& Wickham 1993. Ohman \& Runge 1994), and switching from algal food to ciliates may thus be energetically favourable. It was somewhat surprising that smaller ciliates were not preferred. In laboratory experiments with smaller copepods, ciliates larger than $30 \mu \mathrm{m}$ have been used (e.g. Stoecker \& Egloff 1987, Jonsson \& Tiselius 1990); thus it is difficult to say whether this is a general trend. Ciliates $<30 \mu \mathrm{m}$ may be too small for raptorial feeding by the large Calanus spp., and rather be filtered together with algae in this size fraction. Some small ciliates may also have higher and more irregular swimming patterns than the larger ciliates, making them 
harder to capture individually (Jonsson \& Tiselius 1990) Selective predation on larger ciliates and rotifers by $C$. finmarchicus had a considerable effect on the plankton community development during the $4 \mathrm{~d}$ incubations (L1 and 2). This is in accordance with previous investigations (reviewed by Sanders \& Wickham 1993, Kivi et al. 1993, 1996, Nielsen \& Kiørboe 1994), and shows that copepods may control protozooplankton abundance, which in turn may affect the development of the phytoplankton community and the competition among species.

Algae were generally not preferred food, but due to their high abundance, they always made up the main part of the copepod diet. However, in the last experiment Emiliania huxleyi was grazed at a very high rate (compare Harris 1994. Nejstgaard et al. 1995) and made up as much as $74 \%$ of the daily copepod food intake, while it constituted 'only' $51 \%$ of the prey biomass. The increase of the tood preterence index (Eq. 4) from 0 to 30 for E. huxleyi between $\mathrm{C} 3$ and 4 may be interpreted as a switching behaviour (Chesson 1983), from foraging on various algae to nearly monospecific

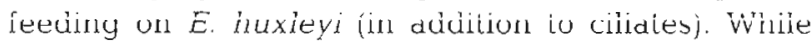
Calanus finmarchicus appeared to be feeding least selectively in Expt C1, when the total food concentration was lowest and dominated by the less preferred $\geq 10 \mu \mathrm{m}$ flagellates, it fed disproportionally on the most abundant food source in $\mathrm{C} 4$. This is in accordance with optimal foraging theory (e.g. DeMott 1989), but is in contrast to previous investigations suggesting that $E$. huxleyi may be of suboptimal size for Calanus spp. (Harris 1994, Nejstgaard et al. 1995), and may not be selected for in natural food suspensions (Nejstgaard et al. 1994). Nevertheless, the high feeding rates recorded in $\mathrm{C} 4$ are in accordance with the high egg production rates recorded here, and support the results in Nejstgaard et al. (1995), suggesting that there is a pronounced seasonal increase in Calanus finmarchicus maximal feeding rates for E. huxleyi during late spring and summer

\section{Egg production}

Unfortunately, no egg production experiments were run during peak biomasses of ciliates. A diet dominated by Emiliania huxleyi supported an unusually high egg production (67 to 81 eggs copepod $\mathrm{d}^{-1} \mathrm{~d}^{-1}$ ), while diets dominated by diatoms did not (compare e.g. Plourde \& Runge 1993), despite the carbon and mitrogen ingestion being similar during both blooms in the NP1 mesocosm. Correspondingly there was a much higher zooplankton biomass increase in both the NP mesocosms compared to the NPS-mesocosms (Table 8)
Copepod ingestion rates were not determined in NPS1 (diatom mesocosm), but the total algae concentration was similar or higher as compared to the NP1 mesocosm (Egge \& Jacobsen 1997). Fatty acid composition of Calanus finmarchicus and Pseudocalanus elongatus copepodids collected in the mesocosms on 20 June strongly indicated diets dominated by Emiliania huxleyi in the NP mesocosms, and diatoms in the NPS mesocosms, respectively (Wang-Andersen 1995). Copepods from the E. huxleyi-dominated mesocosms showed a significantly higher content of the fatty acids $18: 0$ and $22: 6(n-3)$, and ratios of $22: 6(n-3) / 20: 5(n-3)$ and $(n-3) /(n-6)$ groups (Wang-Andersen 1995). These factors are all associated with reproductive success in copepods (e.g. Støttrup \& Jensen 1990, Kleppel \& Burkart 1995, Jónasdóttir et al. 1995, Jónasdóttir \& Kiørboe 1996). Especially the high levels of ( $n-3)$ PUFA in $E$. huxleyi suggest that this species is of very high nutritional value tor reproduction and larval development of zooplankton (Pond \& Harris 1996). This may explain why small haptophytes such as Isochrysis galbana (Støttrup \& Jensen 1990, Ianora et al. 1995), and E. huxieyi (B̊̊nsiedi ei di. unpubi.) nny suppori highi egg production rates and hatching success, at least when in high abundance.

The Emiliania huxleyi dominated blooms, at similar prey concentrations (in terms of organic carbon and/or total nitrogen), provided a superior food source for reproduction of Calanus finmarchicus compared to the diatom blooms dominated by Skeletonema costatum. This novel finding is in accordance with an increasing number of investigations questioning the role of diatoms as a key food for reproductive success in copepods (e.g. Kleppel et al. 1991) and showing that copepods feeding on diatoms (including $S$. costatum) experience high mortality, have low egg production rates and abnormal development of eggs and nauplii (Ianora et al. 1995, Poulet et al. 1995, Runge \& Starr 1996, Uye 1996, and references therein). Note however that Jónasdóttir \& Kiørboe (1996) found no detrimental effects of diatoms on eggs of Acartia tonsa, but concluded that hatching failure in high concentrations of diatom extracts may be due to hypoxia.

\section{Summary}

We conclude that the diatom bloom dominated by Skeletonema costatum stimulated growth of larger protozoan microzooplankters, and became grazer controlled. In contrast, Emiliania huxleyi did not stimulate growth of most protozoans, but escaped grazing control and was able to produce nearly monospecific blooms 
Calanus finmarchicus may feed on many trophic levels, as well as size ranges of almost 2 orders of magnitude. Nevertheless, $C$. finmarchicus always preferred larger ciliates, and may have an indirect effect on the phytoplankton development through predation on the microzooplankton. However, C. finmarchicus was also able to feed on the small Emiliania huxleyi, and E. huxleyi blooms supported a significantly higher egg production compared to the $S$. costatum-dominated diatom blooms.

Microzooplankton grazing and phytoplankton specific growth rates based on chl a measurements appeared to substantially underestimate the true rates, as they accounted only for about half of the rates based on cell counts. When grazing by the microzooplankton is significant, this should be accounted for when calculating copepod grazing rates.

Acknowledgements. We acknowledge: Anita Jacobsen for analysis of the algae samples, Jorun K. Egge for providing data, Per Jonsson, Per Juel Hansen and Lars Johan Naustvoll for kindly providing information on microzooplankton, Egil Erichsen for TEM analysis, Stein Kaartvedt and Ulf Båmstedt for critically reading earlier versions of the manuscript, and Tom Andersen for comments on the manuscript, as well as 4 anonymous referees. This work was supported by grants from the Norwegian Research Council for Science and Humanities (NFR).

\section{LITERATURE CITED}

Andersen P, Sorensen HM (1986) Population dynamics and trophic coupling in pelagic microorganisms in eutrophic coastal waters. Mar Ecol Prog Ser 33:99-109

Andersen T, Schartau AKL, Paasche E (1991) Quantifying external and internal nitrogen and phosphorus pools, as well as nitrogen and phosphorus supplied through remineralization, in coastal marine plankton by means of a dilution technique. Mar Ecol Prog Ser 69:67-80

Atkinson A (1996) Subarctic copepods in an oceanic, low chlorophyll environment: ciliate predation, food selectivity and impact on prey populations. Mar Ecol Prog Ser 130 $85-96$

Båmstedt U (1986) Chemical composition and energy content In: Corner EDS, O'Hara SCM (eds) The biological chemistry of marine copepods. Oxford University Press, Oxford, p 1-58

Båmstedt U, Håkansson JL, Brenner-Larsen J, Björnsen PK Geertz-Hansen O, Tiselius P (1990) Copepod nutritional condition and pelagic production during autumn in Kosterfjorden, western Sweden. Mar Biol 104:197-208

Banse K (1995) Zooplankton: pivotal role in the control of ocean production. ICES J Mar Sci 52:265-277

Berge $G$ (1962) Discoloration of the sea due to Coccolithus huxleyi 'bloom' Sarsia 6:27-40

Birkenes E, Braarud T (1952) Phytoplankton in the Oslo fjord during a 'Coccolithus huxleyi-summer' Avh norske VidenskAkad Oslo Matematisk naturvidenskapelig Klasse $2: 1-23$

Bleijswijk JDL van, Kempers RS, Veldhuis MJW (1994a) Cell and growth characteristics of types $A$ and $B$ of Emiliania huxleyi (Prymnesiophyseae) as determined by flow cytometry and chemical analyses. J Phycol 30:230-241
Bleijswijk JDL van, Kempers RS, Wal P van der, Westbroek P, Egge JK, Lukk T (1994b) Standing stocks of PIC, POC, PON and Emiliania huxleyi coccospheres and liths in sea water enclosures with different phosphate loadings. Sarsia 79:307-317

Bleijswijk JDL van, Veldhuis MJW (1995) In situ growth rates of Emiliania huxleyi in enclosures with different phosphate loadıngs revealed by diel changes in DNA content. Mar Ecol Prog Ser 121:271-277

Blom G, Otterå $H$, Svắsand $T$, Kristiansen TS, Serigstad B (1991) The relationship between feeding conditions and production of cod fry (Gadus morhua) in a semi-enclosed marine ecosystem in Western Norway, illustrated by use of consumption model. ICES Mar Sci Symp 192:176-189

Brand LE (1982) Genetic variability and spatial patterns of genetic differentiation in the reproductive rates of the marine coccolithophores Emiliania huxleyi and Gephyrocapsa oceanica. Limnol Oceanogr 27:236-245

Burkill PH, Mantoura RFC, Llewellyn CA, Owens NJP (1987) Microzooplankton grazing and selectivity of phytoplankton in coastal waters. Mar Biol 93:581-590

Chesson J (1983) The estimation and analysis of preference and its relationship to foraging models. Ecology 64: $1297-1304$

Chisholm SW (1992) Phytoplankton size. In: Falkowski PG, Woodhead AD (eds) Primary productivity and biogeochemical cycles in the sea. Plenum Press, New York, p $213-237$

Dale $T$ (1988) Oil pollution and plankton dynamics. VI. Controlled ecosystem experiments in Lindăspollene, Norway, June 1981: effects on planktonic ciliates following nutrient addition to natural and oll-polluted enclosed water columns. Sarsia 73:179-191

DeMott WR (1989) Optimal foraging theory as a predictor of chemically mediated food selection by suspension-feeding copepods. Limnol Oceanogr 34:140-154

Dolan JR (1991) Guilds of cilate microzooplankton in the Chesapeake Bay. Estuar Coast Shelf Sci 33:137-152

Eccleston-Parry JD, Leadbeater BSC (1994) The effect of long-term low bacterial density on the growth kinetics of three marine heterotrophic nanoflagellates. J Exp Mar Biol Ecol 177:219-233

Edler L (1977) Phytoplankton and primary production in the Sound. PhD thesis, University of Gothenburg

Egge JK (1993) Nutrient control of phytoplankton growth: effects of macronutrient composition (N, P, Si) on species succession. Dr Scient thesis, University of Bergen

Egge JK, Heimdal BR (1994) Blooms of phytoplankton including Emilianla huxleyi (Haptophyta). Effects of nutrient supply in different N:P ratios. Sarsia 79:333-348

Egge JK, Jacobsen A (1997) Influence of silicate on particulate carbon production in phytoplankton. Mar Ecol Prog Ser 147:219-230

Erga SR (1989) Ecological studies on the phytoplankton of Boknafjorden, western Norway. 1. The effect of water exchange processes and environmental factors on temporal and vertical variability of biomass. Sarsia 74:161-176

Erga SR, Heimdal BR (1984) Ecological studies on the phytoplankton of Korsfjorden, western Norway. The dynamics of a spring bloom seen in relation to hydrographical conditions and light regime. J Plankton Res 6:67-90

Frost BW (1972) Effect of size and concentration of food particles on the feeding behaviour of the marine planktonic copepod Calanus pacificus. Limnol Oceanogr 17:805-815

Ferrier C, Rassoulzadegan F (1991) Density-dependent effects of protozoans on specific growth rates in pico- and nanoplanktonic assemblages. Limnol Oceanogr 36:657-669 
Ferrier-Pagès C, Rassoulzadegan F (1994) Seasonal impact of the microzooplankton on the pico- and nanoplankton growth rates in the northwest Mediterranean Sea. Mar Ecol Prog Ser 108:283-294

Fessenden L, Cowles TJ (1994) Copepod predation on phagotrophic ciliates in Oregon coastal waters. Mar Ecol Prog Ser 107:103-111

Gallegos CL (1989) Microzooplankton grazing on phytoplankton in the Rhode River, Maryland: nonlinear feeding kinetics. Mar Ecol Prog Ser 57:23-33

Gismervik I, Andersen T, Vadstein $O$ (in press) Pelagic food webs and eutrophication of coastal waters: impact of grazers on algal communities. Mar Poll Bull

Hansen B, Bjornsen PK, Hansen PJ (1994) The size ratio between planktonic predators and their prey. Limnol Oceanogr 39:395-403

Hansen FC, Reckermann M, Klein Breteler WCM, Riegman R (1993) Phaeocystis blooming enhanced by copepod predation on protozoa: evidence from incubation experiments. Mar Ecol Prog Ser 102:51-57

Hansen FC, Witte HJ, Passarge J (1996) Grazing in the heterotrophic dinoflagellate Oxyrrhis marina: size selectivity and preterence of calcified Emiliania huxleyi cells. Aquat Microb Ecol 10:307-313

Hansen PJ (1.991) Dinophysis-a planktonic dinoflagellate genus which can act both as prey and predator of a ciliate. Mar Biol 114:327-334

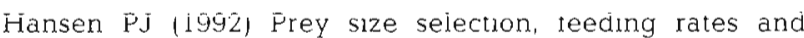
growth dynamics of heterotrophic dinoflagellates with special emphasis on Gyrodinium spirale. Mar Biol 114: $327-334$

Harris RP (1994) Zooplankton grazing on the coccolithophore Emiliania huxleyi and its role in inorganic carbon flux. Mar Biol 119:431-439

Hasle GR (1969) An analysis of the phytoplankton off the Pacific Southern Ocean: abundance, composition and distribution during the 'Brategg Expedition' 1947-1948. Hvalrådets $\mathrm{Skr}$ 52:1-168

Heimdal BR, Egge JK, Veldhuis MJW, Westbroek P (1994) The 1992 Norwegian Emiliania huxleyi experiment. Sarsia $79: 285-290$

Hirche HJ (1990) Egg production of Calanus finmarchicus at low temperature. Mar Biol 106:53-58

Holligan PM, Fernández $E$, Aiken J, Balch WM, Boyd $P$, Burkill PH, Finch M, Groom SB, Malin G, Muller K, Purdie D, Robinson C, Trees CC, Tumer, SM, Wal P van der (1993) A biogeochemical study of the coccolithophore, Emiliania huxleyi, in the North Atlantic. Global Biogeochem Cycles 7:879-900

lanora A. Poulet SA, Miralto A (1995) A comparative study of the inhibitory effect of diatoms on the reproductive biology of the copepod Temora stylifera. Mar Biol 121 $533-539$

Jónasdóttir SH. Fields D, Pantoja S (1995) Copepod egg production in Long Island Sound, USA, as a function of the chemical composition of seston. Mar Ecol Prog Ser 119: $87-98$

Jónasdóttir SH, Kiørboe T (1996) Copepod recruitment and food composition: do diatoms affect hatching success? Mar Biol 125:743-750

Jonsson P (1986) Particle size selection, feeding rates and growth dynamics of marine planktonic oligotrichous ciliates (Ciliophora: Oligotrichina). Mar Ecol Prog Ser 3 265-277

Jonsson P, Tiselius P (1990) Feeding behaviour, prey detection and capture efficiency of the copepod Acartia tonsa feeding on planktonic ciliates. Mar Ecol Prog Ser 60:35--44
Karlson K, Båmstedt U (1994) Planktivorous predation on copepods. Evaluation of mandible remains in predator guts as a quantitative estimate of predation. Mar Ecol Prog Ser 108:79-89

Kiorboe T, Nielsen TG (1994) Regulation of zooplankton biomass and production in a temperate, coastal ecosystem. 1. Copepods Limnol Oceanogr 39:493-507

Kivi K, Kaitala S, Kuosa H, Kuparainen J, Leskinen E, Lignell R, Marcussen B, Tamminen T (1993) Nutrient limitation and grazing control of the Baltic plankton community during annual succession. Limnol Oceanogr 38:893-905

Kivi K, Kuosa H, Tanskanen S (1996) An experimental study on the role of crustacean and microprotozoan grazers in the planktonic food web. Mar Ecol Prog Ser 136:59-68

Kivi K, Setälä O (1995) Simultaneous measurement of food particle selection and clearance rates of planktonic oligotrich ciliates (Ciliophora: Oligotrichina). Mar Ecol Prog Ser 119:125-137

Kleppel GS (1993) On the diets of calanoid copepods. Mar Ecol Prog Ser 99:183-195

Kleppel GS, Burkart CA (1995) Egg production and the nutritional environment of Acartia tonsa: the role of food quality in copepod nutrition. ICES J Mar Sci 52:297-304

Kleppel GS, Holliday DV, Pieper RE (1991) Trophic interactions between copepods and microplankton: a question about the role of diatoms. Limnol Oceanogr 36:172-178

Landry MR (1993) Estimating rates of growth and grazing mortality of phytoplankton by the dilution method. In: Kemp PF, Sherr BF, Sherr EB, Cole JJ (eds) Handbook of methods in aquatic microbial ecology. Lewis Publishers, Boca Raton, p 715-722

Landry MR, Hassett RP (1982) Estimating the grazing impact of marine micro-zooplankton. Mar Biol 67:283-288

Lessard EJ (1991) The trophic role of heterotrophic dinoflagellates in diverse marine environments. Mar Microb Food Webs 5:49-58

Levasseur M, Michaud S. Egge J, Cantin G, Nejstgaard JC Sanders R, Fernándes E, Solberg PT, Heimdal BR. Gosselin M (1996) Production of DMSP and DMS during a mesocosm study of an Emiliania huxleyi bloom: influence of bacteria and Calanus finmarchicus grazing. Mar Biol 126:609-618

Manly BFJ (1974) A model for certain types of selection experiments. Biometrics 30:281-294

Moal J, Martin-Jezequel V, Harris RP, Samain JF, Poulet SA (1987) Interspecific and intraspecific variability of the chemical composition of marine phytoplankton. Oceanol Acta 10:339-346

Montagnes DJS, Berges JA, Harrison PJ, Taylor FJR (1994) Estumating carbon, nitrogen, protein, and chlorophyll a from volume in marine phytoplankton. Limnol Oceanogr 39:1044-1060

Montagnes DJS, Lynn DH (1993) A quantitative protargol stain (QPS) for ciliates and other protists. In: Kemp PF, Sherr BF, Sherr EB, Cole JJ (eds) Handbook of methods in aquatic microbial ecology. Lewis Publishers, Boca Raton, p 229-240

Nejstgaard JC, Båmstedt U, Bagøien E, Solberg PT (1995) Algal constraints on copepod grazing. Growth state, toxicity, cell size and season as regulating factors. ICES J Mar Sci $57: 347-357$

Nejstgaard JC, Witte H, Wal P van der, Jacobsen A (1994) Copepod grazing during a mesocosm study of an Emiliania huxleyi (Prymnesiophyceae) bloom. Sarsia 79:369-377

Neuer S, Knowles TJ (1994) Protist herbivory in the Oregon upwelling system. Mar Ecol Prog Ser 113:147-162

Nielsen TG, Kiørboe T (1994) Regulation of zooplankton bio- 
mass and production in a temperate, coastal ecosystem. 2. Ciliates. Limnol Oceanogr 39:508-519

Nielsen TG, Sabatini M (1996) Role of cyclopoid copepods Oithona spp. in North Sea plankton communities. Mar Ecol Prog Ser 139:79-93

Ohman MD, Runge JA (1994) Sustained fecundity when phytoplankton resources are in short supply: omnivory by Calanus finmarchicus in the Gulf of St. Lawrence. Limnol Oceanogr 39:21-36

Ohman MD. Snyder RA (1991) Growth kinetics of the omnlvorous oligotrich ciliate Strombidium sp. Limnol Oceanogr 36:922-935

Olsen Y, Jensen A, Reinertsen H, Rugstad B (1983) Comparıson of different algal carbon estimates by use of the Droop-model for nutrient limited growth. J Plankton Res 5:43-51

Pierce RW, Turner JT (1992) Ecology of planktonic ciliates in marine food webs. Rev Aquat Sci 6:139-181

Plourde S, Runge JA (1993) Reproduction of the planktonic copepod Calanus finmarchicus in the Lower St. Lawrence Estuary: relation to the cycle of phytoplankton production and evidence for a Calanus pump. Mar Ecol Prog Ser 102:217-227

Pond D, Harris RP (1996) The lipid composition of the coccolithophore Emiliania huxleyi and its possible ecophysiological significance. J Mar Biol Ass UK 76:3

Poulet SA, Laabir M, Ianora A, Miralto A (1995) Reproductive response of Calanus helgolandicus I. Abnormal embryonic and naupliar development. Mar Ecol Prog Ser 129 : $85-95$

Putt M, Stoecker DK (1989) An experimentally determined carbon:volume ratio for marine 'oligotrichous' ciliates from estuarine and coastal waters. Limnol Oceanogr 34: $1097-1103$

Riegman R, Kuipers BR, Noordeloos AAM, Witte HJ (1993) Size-differential control of phytoplankton and the structure of plankton communities. Neth J Sea Res 31:255-265

Runge JA, Starr M (1996) Relationship between the phytoplankton production cycle and recruitment rates in populations of Calanus finmarchicus. Eos (Trans Am Geophys Un) 77(3). Ocean Sciences Meet Suppl, OS1, p 125

Sakshaug E, Andresen K (1986) Effect of light regime upon growth rate and chemical composition of a clone of Skeletonema costatum from the Trondheimsfjord, Norway. J Plankton Res 8:619-637

Sanders RW, Wickham SA (1993) Planktonic protozod and metazoa: predation, food quality and population control. Mar Microb Food Webs 7:197-223

Schnepf E. Elbrächter M (1992) Nutritional strategies of dinoflagellates. Eur J Protistol 28:3-24

Smetacek V (1981) The annual cycle of protozooplankton in the Kiel Bight. Mar Biol 63:1-11

Stoecker DK, Capuzzo JM (1990) Predation on protozoa: its importance to zooplankton. J Plankton Res 12:891-908

Stoecker DK, Egloff DA (1987) Predation by Acartia tonsa

This article was submitted to the editor on planktonic cllates and rotıfers. J Exp Mar Biol Ecol $110.53-68$

Stottrup JG, Jensen J (1990) Influence of algal diet on feeding and egg-production of the calanoid copepod Acartia tonsa Dana. J Exp Mar Biol Ecol 141:87-105

Tsuda A, Nemoto T (1988) Feeding of copepods on natural suspended particles in Tokyo Bay. J Oceanogr Soc Japan 44:217-227

Turner JT (1994) Planktonic copepods of Boston Harbour, Massachusetts Bay and Cape Cod Bay, 1992. Hydrobiologia 292/293:405-413

Uye $S(1996)$ Induction of reproductive failure in the planktonic copepod Calanus pacificus by diatoms. Mar Ecol Prog Ser 133:89-97

Verity PG, Robertson CY, Tronzo CR, Andrews MG, Nelson JR, Sieracki ME (1992) Relationships between cell volume and the carbon and nitrogen content of marine photosynthetic nanoplankton. Limnol Oceanogr 37:1434-1446

Verity PG. Smetacek $V$ (1996) Organism life cycles, predation, and the structure of marine pelagic ecosystems. Mar Ecol Prog Ser 130:277-293

Wal P van der, Kraay GW, Meer J van der (1994) Community structure and nutritional state of phytoplankton growing in mesocosms with different initial N:P ratios studied with high performance liquid chromatography. Sarsia 79 : 409-416

Wang-Andersen J (1995) Fettsyre- og fettalkoholsammensetningen i marine copepoder. Cand Scient thesis, University of Bergen

Waterhouse TY, Welschmeyer NA (1995) Taxon-specific analysis of microzooplankton grazing rates and phytoplankton growth rates. Limnol Oceanogr 40:827-834

Welschmeyer NA \{1994\} Fluorometric analysis of chlorophyll a in the presence of chlorophyll $b$ and phaeopigments. Limnol Oceanogr 39:1985-1992

Westbroek P, Brown CW, Bleijswijk $J$ van, Brownlee $C_{1}$ Brummer GJ, Conte M, Egge J, Fernández E, Jordan R, Knappertbusch M, Stefels J, Veldhuis M, Wal P van der, Young $J$ (1993) A model system approach to biological climate forcing The example of Emiliania huxleyi. Global Planet Change 8:27-46

Wiborg KF (1954) Investigations on zooplankton in coastal and offshore waters of western and northwestern Norway with special reference to the copepods. Fisk Dir Skr (Ser Havunders) 11:1-246

Widdows J (1991) Physiological ecology of mussel larvae. Aquaculture 94:147-163

Wolfe GV, Sherr EB, Sherr BF (1994) Release and consumption of DMSP from Emiliania huxleyi during grazing by Oxyrrhis marina. Mar Ecol Prog Ser 111:111-119

Wolfe GV, Steinke M (1996) Grazing-activated production of dimethylsulphide (DMS) by two clones of Emiliania huxleyi. Limnol Oceanogr 41:1151-1160

Zar JH (1996) Biostatistical analysis, 3rd edn. Prentice Hall, Upper Saddle River, NJ

Manuscript first received: February 16, 1996 Revised version accepted: December 4, 1996 